\section{Między słowem a obrazem. $Z$ notatnika reżysera}

Film robi się przed zdjęciami. Wszystko, co istotne dla filmu, trzeba wymyślić i opracować, zanim staniesz na planie filmowym. Scenariusz, obsadę, sposób kręcenia. Postacie, ich głębię i intensywność. Narrację, inscenizację, a nawet pierwszy układ montażowy. Potem zostaje tylko „wycinanie laubzegą” - jak mówi Andrzej Wajda.

Stara, sprawdzona recepta na film głosi - zanim zaczniesz kręcić, musisz sobie odpowiedzieć na trzy podstawowe pytania: „co?”, „dlaczego?”, „jak?”.

„Co" - to treść filmu np. anegdota albo akcja lub bohater, czyli to, co chce reżyser opowiedzieć.

Drugie pytanie „dlaczego?” dotyczy przesłania, problemu, idei, myśli, czyli tego, co chce reżyser przekazać.

Trzecie ,jak?” to pytanie o formę, o język, o konwencję, o inscenizację, scenopis, czyli w jaki sposób reżyser chce wyrazić „,co” i „jak”.

Odpowiedź na dwa pierwsze pytania („co” i „dlaczego”) powinna znajdować się w scenariuszu. Na trzecie pytanie musi odpowiedzieć reżyser, który przygotowuje się do realizacji.

Scenariusz jest gotowy. Reżyser jest przed zdjęciami. Zna odpowiedź na pytanie „co?” kręci, bo o tym opowiada jego scenariusz. Wie też „dlaczego?” chce ten film nakręcić, bo odpowiedź na to wynika ze scenariusza. Możemy więc założyć, że reżyser znalazł temat i tekst, czuje problem i wie, co chce przekazać.

Nie wie tylko jeszcze ,jak?”.

Następuje bardzo istotny okres w pracy reżysera nad filmem. Szukanie odpowiedzi na pytanie „jak?”. Jak opowiedzieć kamerą scenariusz? Jak poprowadzić aktorów? Jaką zbudować inscenizację? W jaki sposób przekazać, to co jest ważne w scenariuszu? W jaki sposób przekazać myśl?

Okres między scenariuszem a zdjęciami tzw. okres przygotowawczy to czas niezwykle intensywnej pracy dla reżysera. To także czas bardzo intymny, bo wtedy reżyser musi sam ze sobą "pogadać” i zdecydować, jaki film chce zrobić, w jakiej konwencji. Musi rozpocząć żmudną wędrówkę w poszukiwaniu pomysłów na obraz, na ujęcia, na kadry, na grę aktora, na światło, kolor, dźwięk, muzykę. Czyli musi znaleźć odpowiedź na pytanie „jak?”

W tym najbardziej twórczym okresie, gdzie wyobraźnia powinna pracować na dwieście procent, musi urodzić się koncepcja wizualna całego filmu. Reżyser musi przerwać myślenie słowami, ideami, analizami, problemami, teraz musi myśleć obrazem.
Images

vol.VIII/no. 15-16

Poznań 2011

ISSN 1731-450x
Film robi się przed zdjęciami

- szukanie odpowiedzi na ,jak?” 


\section{Co trzeba zrobić przed zdjęciami?}

\section{Rozbicie scenariusza na ujęcia}

Często reżyserzy bagatelizują ten okres pracy nad filmem. Niektórzy uważają, że najważniejszy jest zapis literacki, czyli scenariusz (Krzysztof Zanussi), inni, że zdjęcia (Roman Polański), jeszcze inni, że montaż (Krzysztof Kieślowski). Byli jednak tacy, którzy okres koncepcyjnej pracy nad wizualną stroną filmu (czyli na długo przed zdjęciami) uważali za podstawową część wysiłku twórczego, na przykład Orson Welles czy Alfred Hitchcock.

Jak najlepiej przy pomocy kamery opowiedzieć o tym, co zostało napisane w scenariuszu. Bo można opowiadać „siedząc” aktorowi na twarzy albo opowiadać $\mathrm{z}$ dystansu. Można opowiadać detalami albo planami ogólnymi. Krótkimi ujęciami albo długimi. Można je zrobić ze statywu, z ręki albo z płynnej jazdy.

Kiedyś ze studentami łódzkiej Szkoły Filmowej próbowaliśmy obliczyć, na ile sposobów można opowiedzieć prostą scenę dialogową. ON i ONA siedzą przy stoliku w kawiarni - pada jedna kwestia, ONA wstaje i wychodzi. Otóż okazało się, że można taką prostą sytuację nakręcić na przeszło 30 sposobów (!) i każdy wariant będzie inny.

Możemy ustawić kamerę w różnych miejscach, skręcić tę kawiarnianą scenę w zróżnicowanych planach, a aktorów zmusić do ekspresyjnej, neurotycznej gry. I potem dynamicznie zmontować materiał, a osiągniemy efekt jak w filmach Tarantino.

Możemy zbudować inscenizację płaszczyznową i aktorów uspokoić. Potem skupimy się na bliskich planach twarzy i skręcimy je w długich wytrzymanych ujęciach. Wtedy jak w Personie Bergmana złapiemy dziwny psychologiczny klimat sceny.

Możemy uruchomić kamerę, która będzie w ciągłym ruchu. Jak w filmach Miklósa Jancsó, kamera będzie opisywać tę sytuację, postacie, rekwizyty.

Możemy ustawić aktorów w inscenizacji głębinowej i skręcić naszą scenę w jednym ujęciu, jak zrobił to Orson Welles w Obywatelu Kane (scena, gdy mały Kane jest zabierany do miasta przez prawnika). I tak dalej, i tak dalej...

Jeśli tyle jest różnych możliwości opowiedzenia, a co za tym idzie rozbicia na ujęcia sceny bardzo prostej, to ileż możliwości będzie w scenie bardziej skomplikowanej?

Świadomy wybór i opracowanie metody kręcenia zdjęć, sposobu opowiadania, ustawienia i prowadzenia kamery należy do fundamentalnych zadań reżysera. Trzeba je wykonać przed okresem zdjęć. Po prostu reżyser powinien przygotować się do zdjęć. Nieprzygotowany reżyser to zmora okresu zdjęciowego, z której rodzi się kolejna zmora, tym razem ekranowa.

\section{A. SCENA FABULARNA}

Scena fabularna to zasadniczy budulec każdego filmu. W scenariuszu możemy spotkać się z wieloma rodzajami scen: $\mathrm{np}$. scena dialogowa, scena akcji, pasażowa, retrospektywna. Ułożone w odpowiedniej kolejności tworzą akcję filmu. 
Istnieją cztery podstawowe metody rozbicia sceny na ujęcia:

1. Master shot z przebitkami. Robimy podstawowe, przewodnie ujęcie, które rejestruje całą lub znaczną część sceny. Do niego dokręcamy kilka krótkich ujęć z innych ustawień kamery. Pokazują one fragmenty sceny w innym planie i z innego kąta. W montażu ujęcie podstawowe jest przecinane przebitkami. Metoda ta znajduje zastosowanie przede wszystkim $\mathbf{w}$ scenach dialogowych.

2. Kilka master shotów. Dwa lub więcej. $Z$ różnych stron i w różnych planach. W montażu przecinamy je ze sobą. Krzyżujemy. Metoda ta również znajduje najczęstsze zastosowanie $\mathbf{w}$ scenach dialogowych.

3. Jedno długie ujęcie, które rejestruje całą scenę. Można je stosować do sceny każdego rodzaju.

4. Wiele ujęć - scena montażowa. Kręcimy scenę po kawałku, w wielu ujęciach, $\mathrm{z}$ różnych ustawień kamery. Najczęściej stosuje się tę metodę w scenach akcji.

Większość scen w moim filmie Wszystko co najważniejsze była kręcona metodą master shotu $\mathrm{z}$ przebitkami. Bohaterka filmu wraz z synem zostaje zesłana do Kazachstanu, gdzie walczy o życie, godność i przetrwanie. Film ma charakter szerokiej, epickiej opowieści. Dlatego jako sposób opowiadania wybrałem metodę klasycznych mastershotów. Spójrzmy na dwie sceny z tego filmu. Pierwszy przykład (il.1) opiera się na klasycznym mastershocie ustawionym na oficera NKWD, który przesłuchuje Olę Watową (bohaterka filmu) i chce ją namówić na przyjęcie sowieckiego paszportu. Oficer chodzi, oddala się od kobiety, przybliża, wykonuje różne czynności, po to by w finale sceny podejść bardzo blisko do niej i rzucić w twarz zimną groźbę. Przebitki z kontrowego ustawienia kamery pokazują siedzącą Olę Watową (w bliskim planie), która odmawia przyjęcia paszportu.

Ta scena, to klasyczny pojedynek na argumenty, na sprzeczne racje bohaterów, gdzie każdy dąży do innego celu i chce pokonać przeciwnika. Dlatego master shot jest spokojny, idzie za ruchem postaci, koncentruje się na twarzy, jak u gracza w pokera. W przebitkach na Olę Watową kamera jest skupiona na jej zbliżeniu, nie wykonuje żadnych ruchów. Dla bohaterki to rozgrywka o największą wartość -
Ilustracja 1 


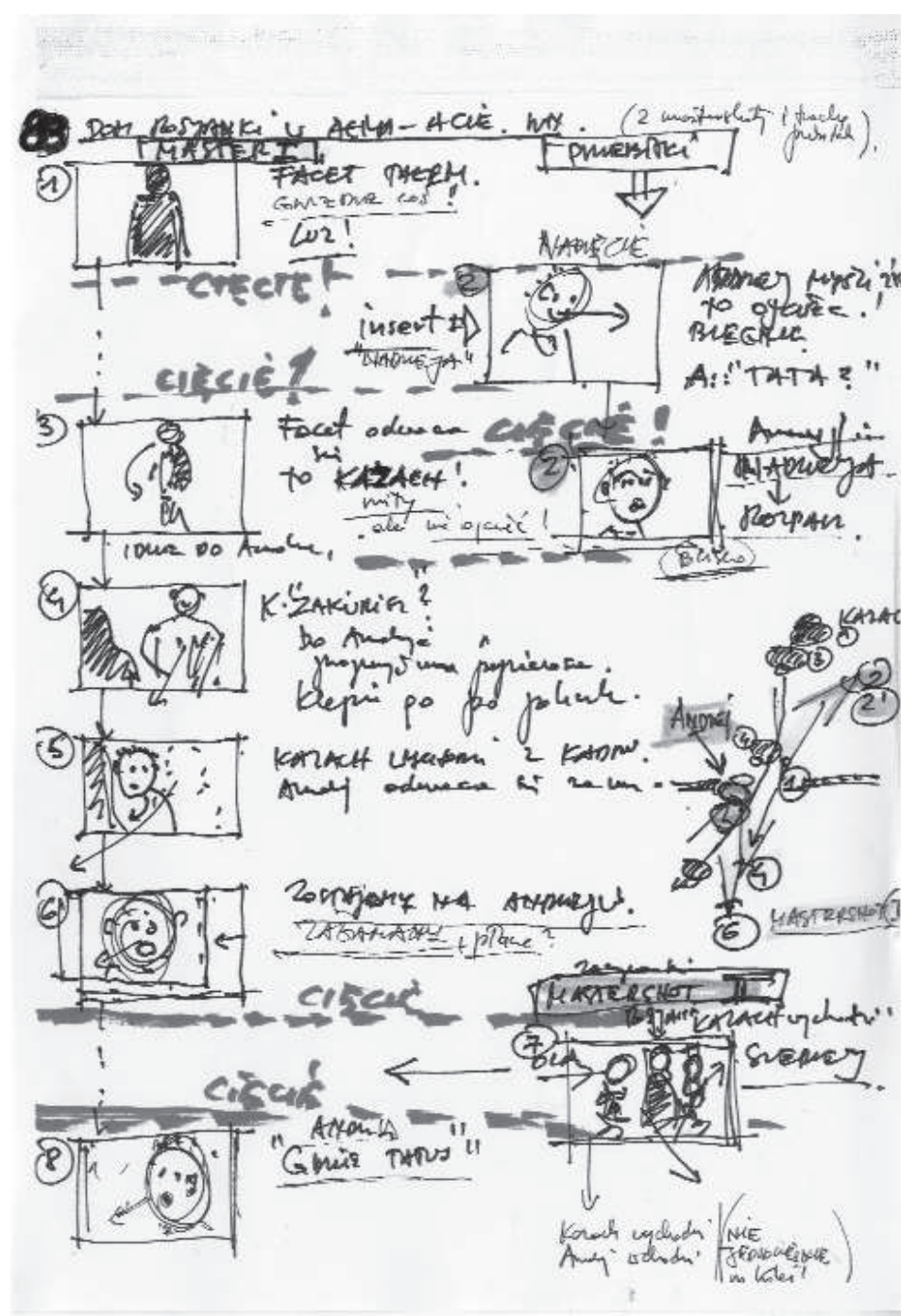

o życie, najważniejszym elementem w kadrze są oczy kobiety, która chce przechytrzyć NKWD-zistę.

Przykład drugi (il.2) składa się z dwóch master shotów, ale ułożonych po kolei, jeden pokrywa pierwszą część sceny, drugi następną część. Rozbicie sceny na dwa master shoty zostało podyktowane trudnymi warunkami wnętrza naturalnego, gdzie zdjęcia były kręcone. Mała kuchnia i maleńki pokoik nie pozwoliły na wykonanie jednego pełnego master shotu tej sceny. Do mastershotów dokręciłem przebitki z kontrowych ustawień. Takie rozwiązanie należy do klasycznych, skręcony materiał w pełni pokazywał wszystkie ważne elementy tej sceny, relacje między postaciami, ruch, napięcia $\mathrm{w}$ bohaterach.

Jeszcze większy komfort daje kręcenie sceny przy pomocy jednoczesnych kilku master shotów, z różnych ustawień kamery i w różnych planach. Dzięki temu mamy dużo swobody w montażu. Możemy nie tylko zdynamizować narrację, ale także ją zwolnić. Możemy scenę zmontować tak, by usunąć w cień postać, która nam się nie sprawdziła. To najbardziej bezpieczna metoda kręcenia, zarówno dla aktora, jak i reżysera. Niestety, ma jedną wadę. Pochłania ogromne ilości taśmy, co w polskich warunkach bywa często problemem.

Dwie bohaterki Cześć Tereska grały scenę na cmentarzu, gdzie „obalały winko" (pierwsze wino Tereski) i rozmawiały o życiu. Od początku prób miałem kłopot z tą sceną. Wielokrotnie poprawialiśmy dialog na próbach. Dziewczyny, Renata i Tereska, rozmawiały swoim językiem, ale było w tym coś fałszywego. Jakaś deklaracyjność, ogólnikowość. Scena nie miała konfliktu w dialogu. Trzeba było ją diametralnie zmienić. Ale jak? Nie wiedziałem. Wtedy postanowiłem, że zrobimy ją metodą improwizacji. Aktorki-amatorki będą mówić swoim tekstem. Metoda nakręcenia powinna więc pozwolić im na swobodę. Duży margines swobody powinien mieć także montażysta. Zaplanowaliśmy dwa główne ustawienia master shotowe na każdą z dziewczyn. Posadziliśmy je przy grobie. Gdy kamery zostały ustawione, powiedziałem na ucho Renacie: spytaj Tereskę, czy boi się śmierci. Cokolwiek odpowie - nie zgadzaj się. Włączyliśmy kamery. Tereska nie znała pytania. Była zaskoczona. Odpowiedziała. Renata kłóciła się z nią. Rodził się konflikt. I niezwykła prawda w pauzach, 
gestach, a przede wszystkim w treści. Umówiłem się z Renatą, że jak zabraknie jej konceptu ma sięgnąć po wino i napić się $\mathrm{z}$ gwinta. To był sygnał do zatrzymania kamer. Wtedy wymyślałem następne pytanie i powtarzaliśmy wszystko. Picie z butelki było przebitką, łącznikiem wariantów master shotowych. Po kilkunastu takich ujęciach miałem bogaty, wspaniały materiał. Ideę nakręcenia sceny na cmentarzu pokazuje ilustracja 3. Scenorys tej sceny ma charakter luźny, jest zapisem idei. Ostateczna wersja tej sceny powstała w montażu. Musiałem więc w scenorysie tylko przewidzieć zasady montażu tej sceny.

Najtrudniejszą scenę aktorską w Cześć Tereska (końcowa spowiedź Tereski u Edzia, którego w finale sceny bohaterka zabija) zrealizowałem przy pomocy dwóch centrycznych master shotów. Pomysł takiego nakręcenia wyniknął z ruchu aktorów, który został opracowany na próbach przed zdjęciami. Był to ruch po dwóch okręgach o wspólnym środku. Tereska poruszała się wolno po okręgu, Edzio na wózku inwalidzkim posuwał się za nią. Również po okręgu, tylko o mniejszym promieniu. Dwa centryczne okręgi ruchu aktorów narzuciły pomysł ustawienia dwóch centrycznych master shotów. Jeden był ustawiony na Tereskę (z punktu widzenia Edzia), drugi odwrotnie na Edzia (z punktu widzenia Tereski). W montażu miałem ogromny komfort. Mogłem dowolnie krzyżować ujęcia, a nawet wydłużyłem niektóre reakcje aktorów (il.4). Scenorys dawał elastyczność w realizacji oraz pozwalał na warianty kamerowe. Dialog w tej scenie był ustalony i aktorzy nie zmieniali go!

Długie ujęcie stawia reżysera przed ostatecznym wyborem. Po nakręceniu długiego ujęcia, niczego nie można zmienić w montażu. Tempo, rytm, akcenty muszą zostać takie, jak zostały nakręcone.

Długie ujęcie to samodzielna scena. Stwarza to niebywały komfort dla aktora, który gra bez przerwy i może wejść silnie w emocje postaci, stworzyć spójny psychologicznie oraz ruchowo portret bohatera. Z drugiej strony długie ujęcie jest gorsetem, w którym wszystko musi zabrzmieć na najwyższym tonie. W długim ujęciu aktor nie może się pomylić. Długie ujęcie wymaga od aktora najwyższej precyzji i techniki, a od kamery dokładnie zaplanowanego ruchu. Związek tych dwóch elementów (aktor i kamera) jest najważniejszy przy kon-
Ilustracja 3 


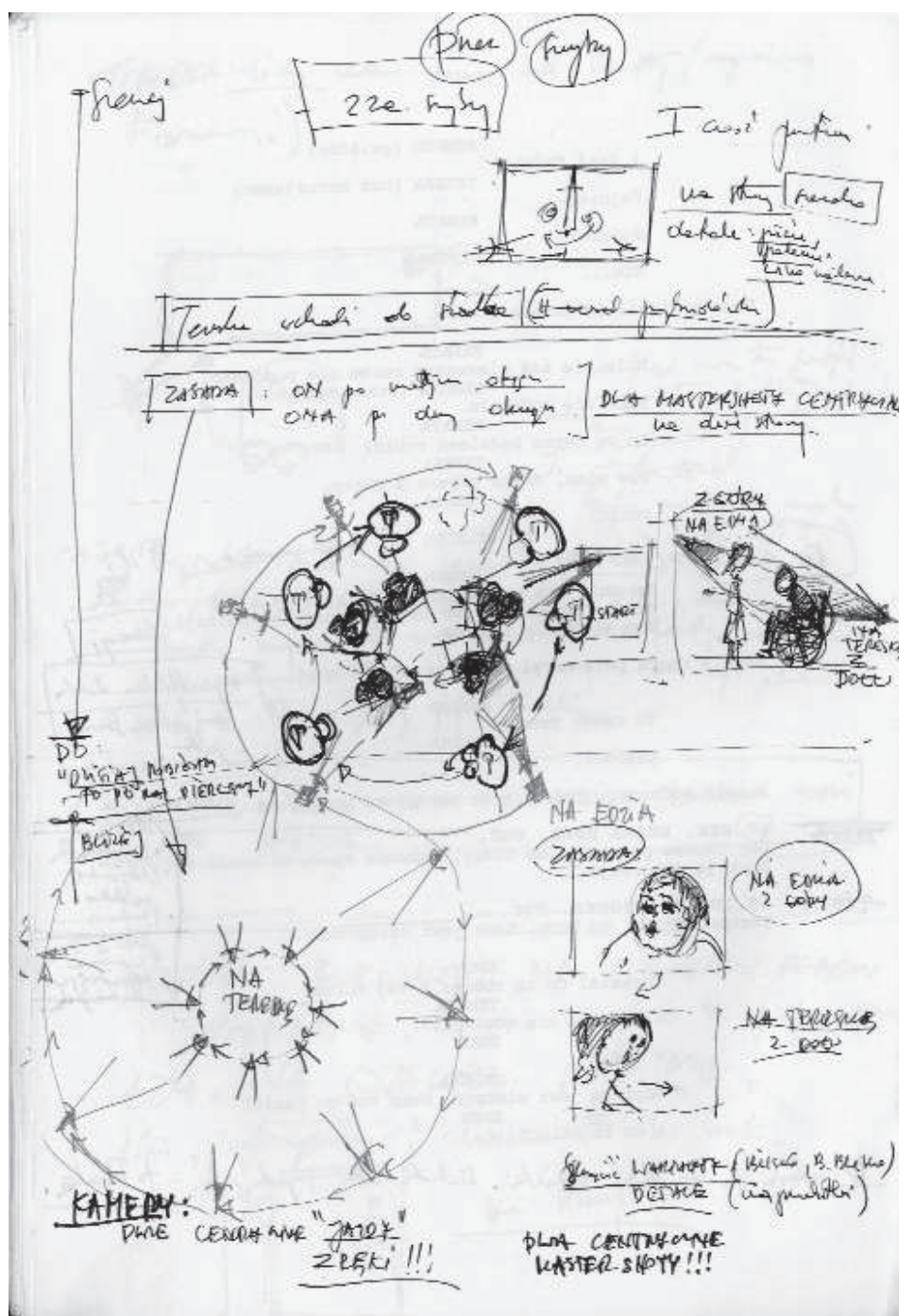

struowaniu długiego ujęcia. Relacja ta może układać się na cztery sposoby:

- kamera za ruchem, jest podporządkowana ruchom w kadrze

- kamera zachowuje się samodzielnie i jej ruch, rytm wyznaczają: albo treść sceny, albo znaczenia, albo emocje postaci

- kamera porusza się mechanicznie, swoim własnym rytmem, ignoruje ruch i emocje aktora, ignoruje znaczenia.

- kamera jest statyczna, ruch aktora opiera się na tzw.montażu wewnątrzkadrowym.

W pierwszej relacji aktor „ciągnie" kamerę za sobą. Kamera jest służebna wobec aktora i jego działań. Jest funkcjonalna, bo opisuje to, co się dzieje. Aktor idzie - kamera podąża za nim; aktor podnosi rękę - kamera panoramuje za ręką; aktor upada - kamera pokazuje upadek aktora. Słynna scena początkowa w Dotyku zła Orsona Wellesa skręcona została w jednym ujęciu. Kamera pokazuje zamachowca, który szykuje bombę, potem widzimy, jak ją podkłada pod samochód, który zmierza do granicy amerykańskomeksykańskiej. Kamera towarzyszy pasażerom samochodu, razem $\mathrm{z}$ nimi przekracza granicę i w finale pokazuje, jak samochód wylatuje $\mathrm{w}$ powietrze

Druga relacja daje kamerze możliwość wyboru znaczeń w scenie. Kamera pokazuje to, co jest ważne. Samodzielnie (czyli z woli reżysera) podąża za wydarzeniami, za emocjami lub reakcjami aktorów. Skupia się na tym, co jest istotne w danej scenie. Ten sposób opowiadania często stosował w swoich filmach węgierski reżyser Miklós Jancsó, którego styl opowiadania charakteryzuje się długimi ujęciami, opisującymi ważne wydarzenia społeczne lub polityczne rozgrywające się w otwartych plenerach, filmy: Desperaci, Gwiazdy na czapkach, Dopóki lud prosi, Elektra,moja miłość. W finale Rozmowy Coppola często używa kamery, która podporządkowana emocjom bohatera, usiłuje wyjaśnić tajemnicę.

W trzeciej relacji kamera sama $\mathrm{z}$ siebie wykonuje mechaniczny ruch, opisuje rzeczywistość i działania aktorów, które zostają jej podporządkowane. Kamera niesie ze sobą wyraźną intencję, działa poza rzeczywistym czasem. Buduje formę sceny. Słynne 7-minutowe ujęcie w Zawód: reporter Antonioniego, zbudowane zostało na jedno- 
stajnym, mechanicznym ruchu kamery, która wyjeżdża z pokoju hotelowego Nicholsona, robi objazd podwórka i wraca do pokoju. Ta dziwna figura symbolicznie podkreśla upływ czasu - w końcu ujęcia widzimy, że bohater nie żyje.

Czwarta relacja polega na tym, że kamera stoi na statywie, aktorzy chodzą, wychodzą, przechodzą - dynamikę sceny budują przez swój ruch. Tak zbudowany jest film Roy Anderssona Pieśni $z$ drugiego piętra, każda $\mathrm{z}$ czterdziestu sześciu scen $\mathrm{w}$ tym filmie to jedno statyczne ujęcie oparte na ruchu wewnątrzkadrowym.

Muszę się przyznać - długie ujęcie jest od lat moją miłością. Niestety nieodwzajemnioną. Często chciałem kręcić tą metodą. Prawie zawsze nie starczało mi odwagi. Po skręceniu sceny w jednym długim ujęciu robiłem kontrowe przebitki - na wszelki wypadek. Z gorącym postanowieniem, że na pewno ich nie użyję. Potem w czasie montażu „pękałem”, ciąłem długie ujęcie. Chcąc nie chcąc, z długiego ujęcia robił się master shot $\mathrm{z}$ przebitkami. Albo co gorsze - scena montażowa!

Kiedyś udało mi się skręcić scenę w długim ujęcie z amatorami, na dodatek $\mathrm{z}$ dziećmi w swoim debiucie fabularnym (scena zabawy w posągi w Niedzielnych igraszkach). Największemu wrogowi nie życzę. Scena była krótka. Trwała półtorej minuty. Opanowanie gromady dzieciaków, wyćwiczenie układów ruchowych i powiązanie ich z kamerą kosztowało mnie dzień zdjęciowy. I kilometr taśmy. Nie mówiąc o awanturze z kierownikiem produkcji, który obsobaczył mnie za marnowanie czasu i pieniędzy na fanaberie.

Pomysł ujęcia opierał się na jeździe kamery, połączonej z panoramą 360 stopni. Kamera porusza się za parą małych aktorów, którzy chodzą między „posągami” - figurami ułożonymi przez inne dzieci. Założenie i zależności ruchowe (para „przewodników”, jazda kamery, dzieci „posągi”) wymusiły na mnie, na aktorach i operatorze ogromną dyscyplinę realizacyjną. Jazda, ustawienia kamery do tej sceny zostały bardzo precyzyjnie przygotowane (rzut il.5). Storyboard (il.6, il.7, il.8) pokazuje kolejność kadrów.

Metoda wielu ujęć, z różnych ustawień kamery, polega na dzieleniu sceny na małe jednostki. Jest to metoda stosunkowo pracochłonna, bo wymaga wielu ustawień kamery. I nie aktorska. Aktor grając postać małymi kawałkami, czasem po jednej kwestii, może zgubić prawdę psychologiczną i ciągłość emocji. Bo ślizga się po powierzchni postaci. Dlatego najczęściej metoda wielu ujęć jest używana w scenach akcji, które nie wymagają głębokiego rysunku psychologicznego, a muszą uwieść widza rytmem cięć montażowych. Sceny gonitw, bijatyk, ucieczek, sceny masowe, sceny walki albo gry w piłkę najczęściej kręci się tą metodą. Aby każda z tych scen była dobra, musi składać się z wielu ujęć. Scenorys takiej sceny musi być precyzyjny, powinien przewidzieć zasadę montażową, rytm i płynność narracyjną, ale przede wszystkim musi zagwarantować dużą ilość różnorodnych ujęć (w różnych planach i różnych ustawieniach). 
Ilustracja 5

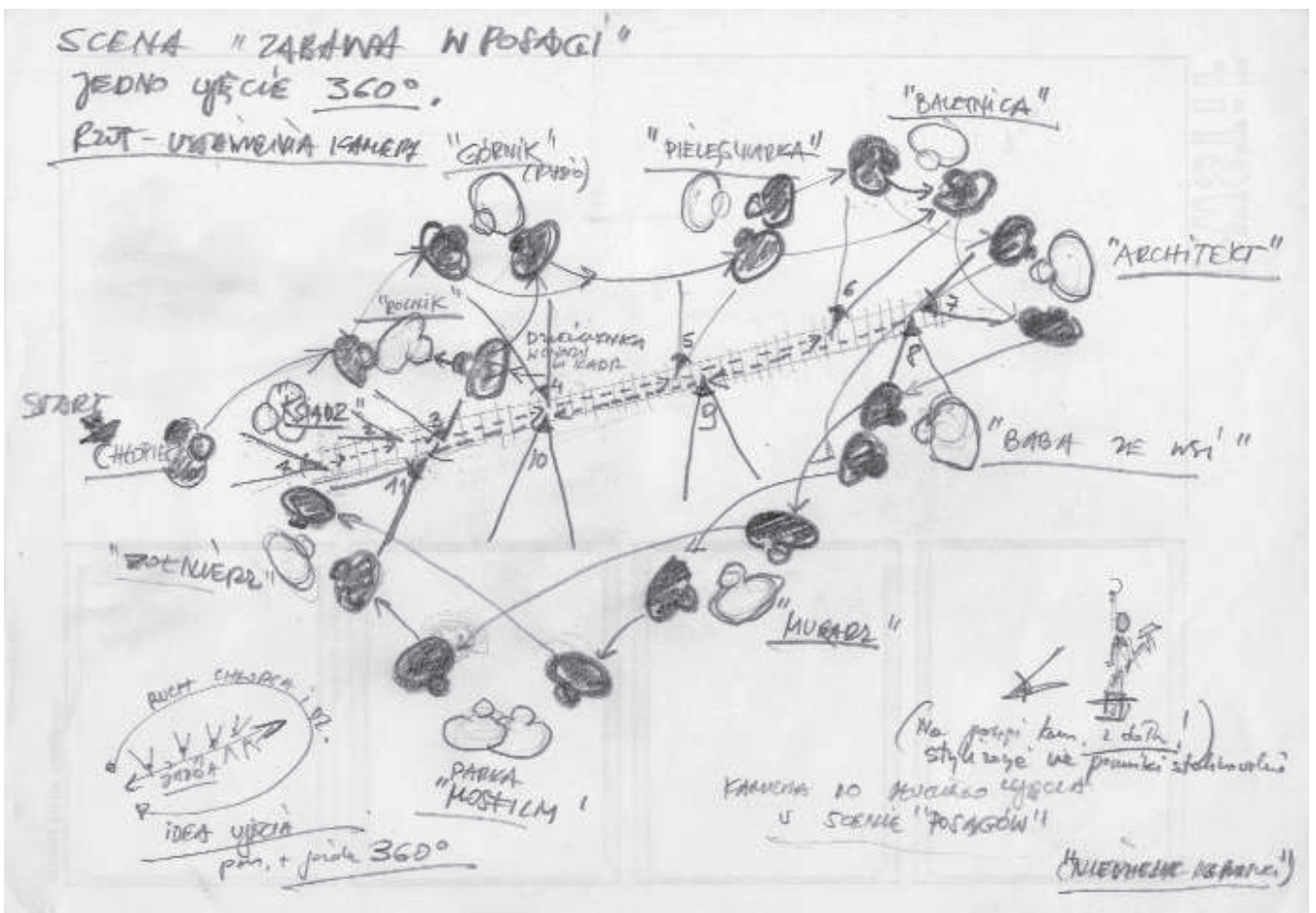

Ilustracja 6

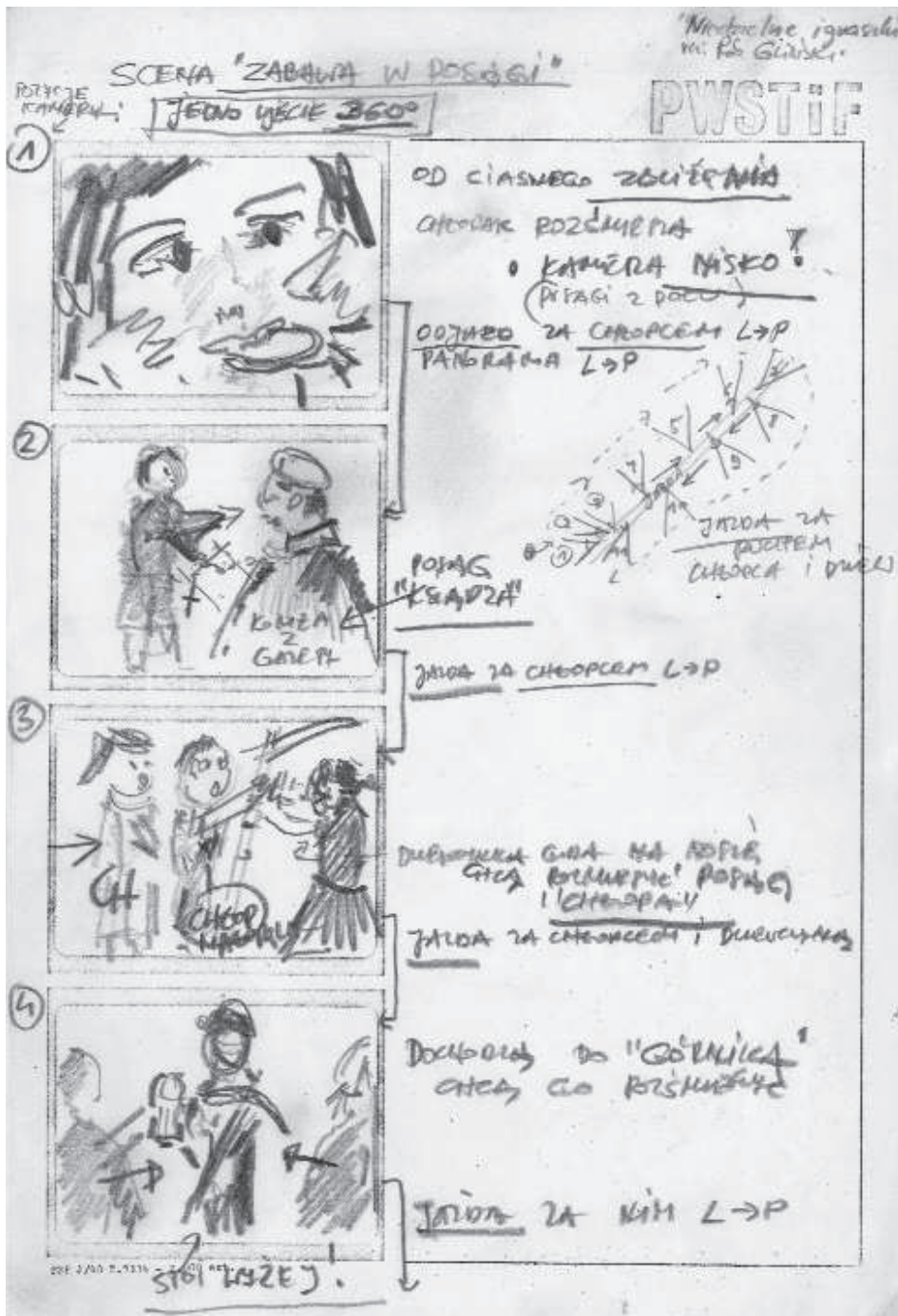

Ilustracja 7

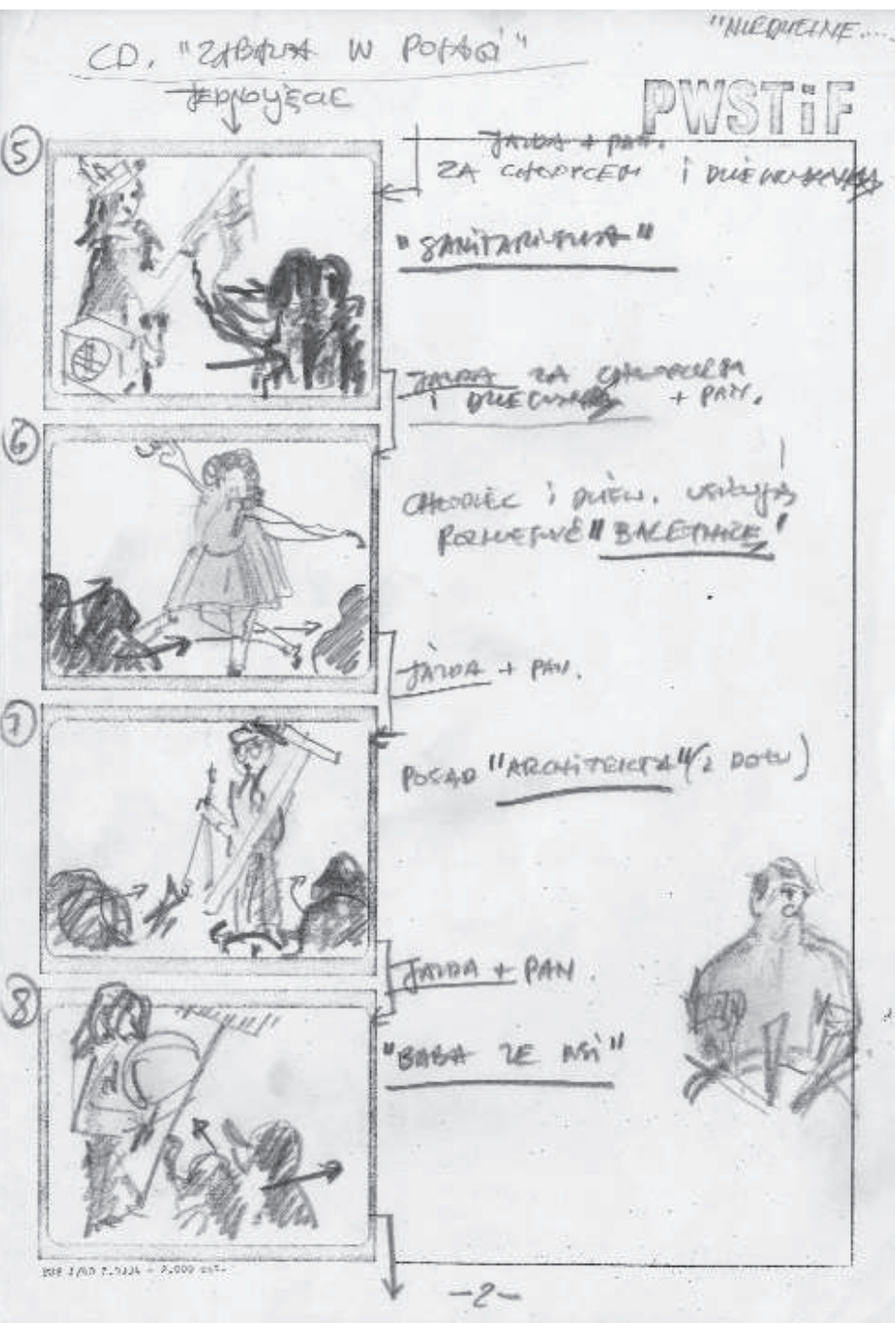




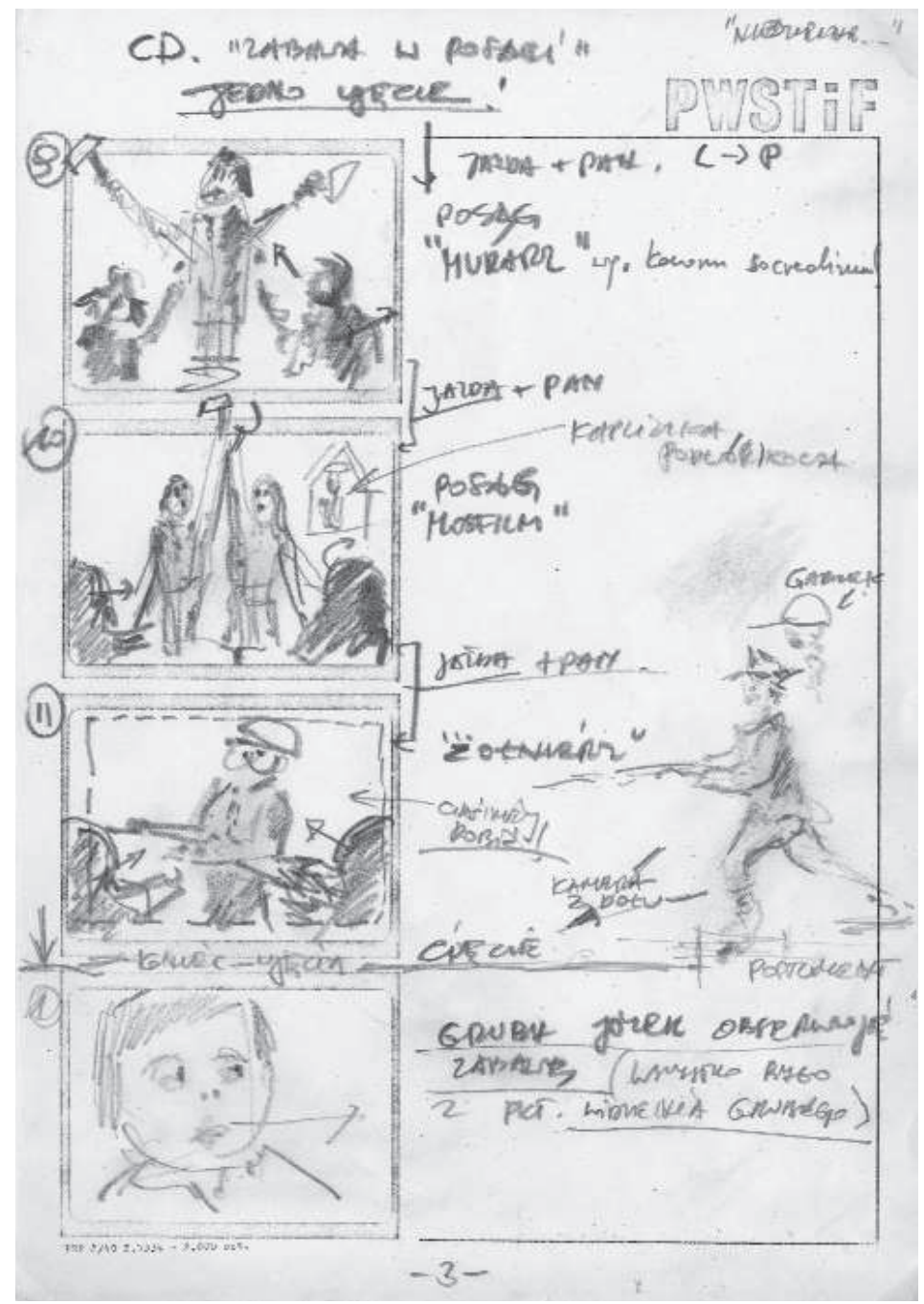

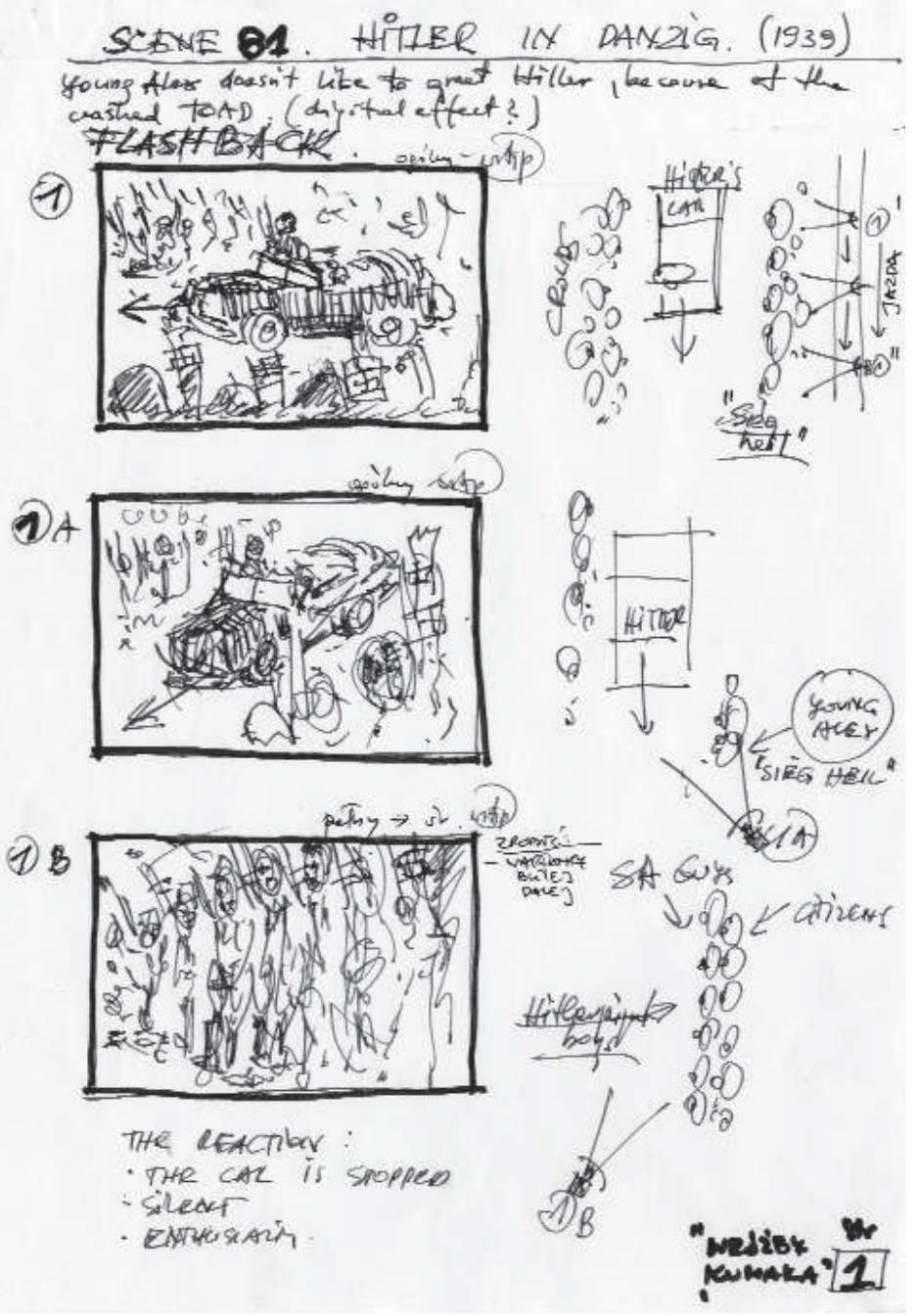

Ilustracje 8 i 9
Scena wjazdu Hitlera do Gdańska w filmie Wróżby kumaka (opowieść magiczno-historyczna oparta na prozie Güntera Grassa) była kręcona na dwie kamery. To scena masowa - wystrojona ulica Długi Targ, kilkuset statystów, samochody dostojników hitlerowskich. Przeważają tu plany szerokie, gęste, pełne ludzi i ruchu. Jednocześnie, obok wiwatującego tłumu, rozgrywa się kameralny dramat chłopca i żaby, który musiał być skręcony ze skupieniem, w bliskich planach. Kontrast (szerokie i bliskie plany) podkreślają siłę emocji chłopca oraz zapowiadają ogromny wpływ tej sceny na dalsze życie bohatera. Ilustracje 9, 10 i 11 pokazują zapis scenariuszowy sceny, rzuty ustawienia kamer oraz ideę kadrowania.

Jak zacząć film? Jak zbudować scenę lub sekwencję początkową? Jak zakomponować napisy początkowe? To bardzo ważne, bo wprowadza widza... właśnie! - w co?

W klimat filmu? W akcję? W gatunek? W bohatera? W problematykę? Wybór należy do reżysera. Istotne jest, aby czołówka jedną lub kilka $\mathrm{z}$ tych funkcji spełniała.

Jeśli już wiemy, co chcemy przez otwarcie powiedzieć - to teraz musimy wpaść na pomysł, jak to opowiedzieć. Pomysł na czo-

\section{B. OTWARCIE FILMU}



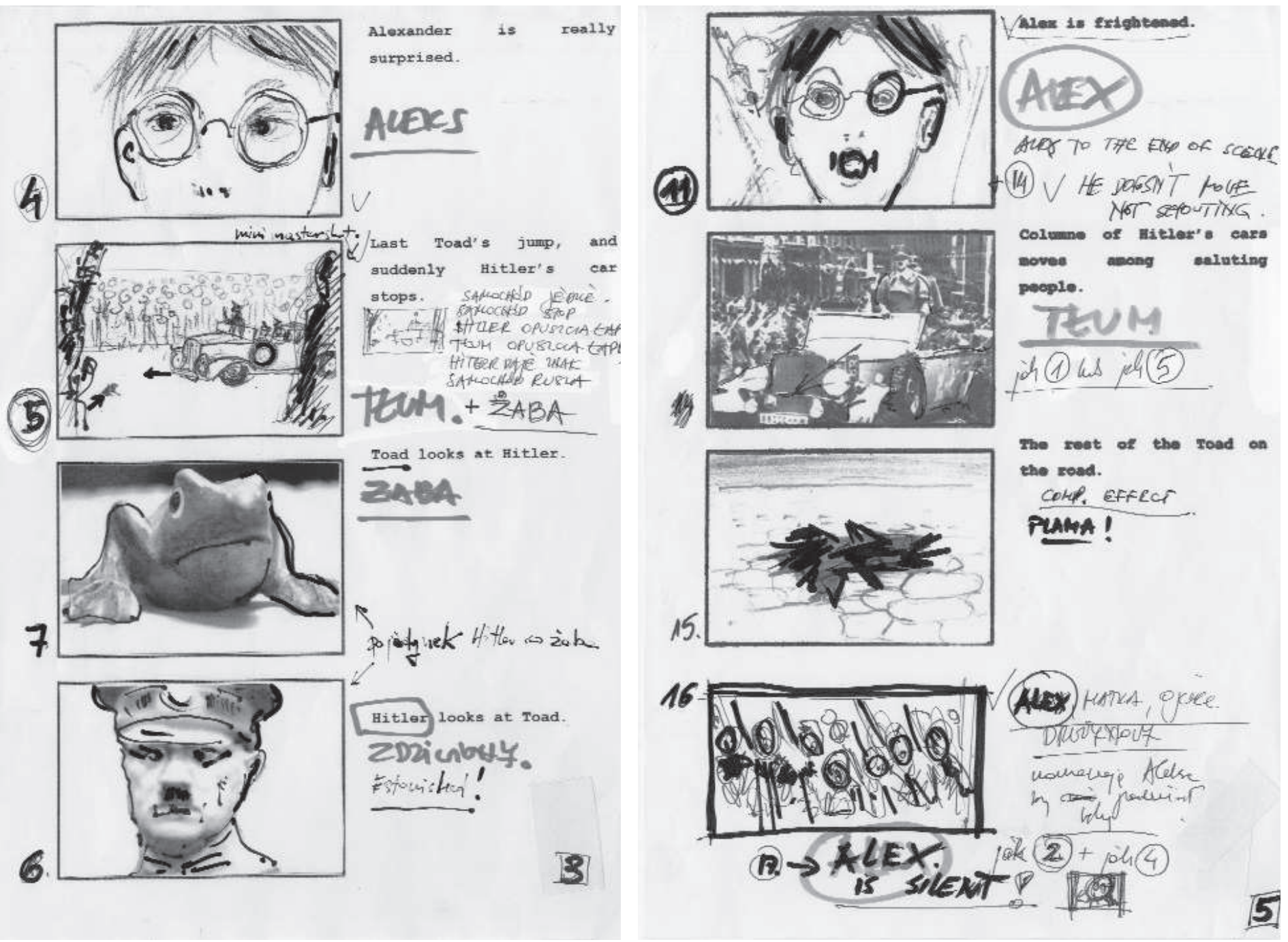

Ilustracje 10 i 11

łówkę często rodzi się miesiącami. Ulega zmianom, korektom - słowem: dojrzewa. Nie wyobrażam sobie sytuacji, by można było wymyślić sekwencję początkową filmu ad hoc, na planie filmowym w czasie zdjęć. Bo będzie wtedy niedopracowana, szkicowa, wtórna lub byle jaka.

Prześledźmy dwa przykłady, które pokazują skrajnie odmienne myślenie o otwarciu filmu:

Mój film Matka swojej matki jest dramatem psychologicznym. Bohaterka to młoda dziewczyna rozdarta między miłościami do dwóch swoich matek, biologicznej i psychicznej. Czołówka tego filmu jest bardzo prosta. Składa się z ciągu bliskich planów (detale) bibelotów, które kobiece ręce przesypują np. koraliki i muszelki, albo przekładają np.fotografie i rysunki dziecięce, albo pakują np. dokumenty. Ciąg tych kadrów (w zwolnionym ruchu) jest gwałtownie przerywany napisami początkowymi (na czerni). Ten szarpany rytm podkreślony został gwałtowną muzyką skrzypcową (Paganini). Gdy napisy się kończą, odjazd kamery pokazuje bohaterki filmu, które pakują swoje rzeczy do przeprowadzki. Czołówka ta wprowadza nas w akcję filmu (wyjazd bohaterek), pokazuje świat, w którym żyją (ciepły dom rodzinny), a muzyka sygnalizuje pasję jednej z bohaterek (gra na skrzyp- 


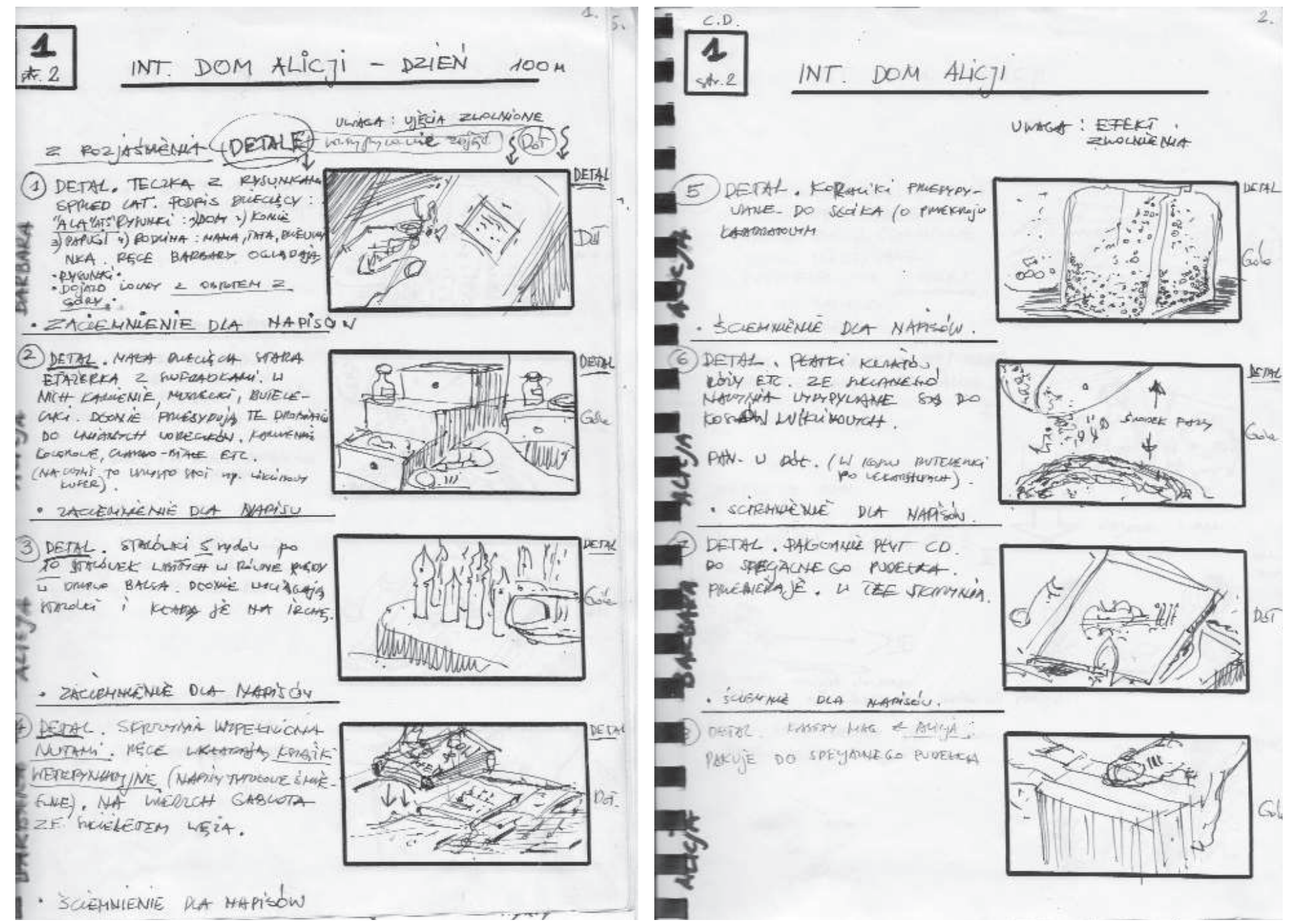

cach). Zmienny rytm narracji, zderzenie płynności z agresją zapowiadają konflikt, który będzie treścią filmu. Ilustracje 12, 13 i 14 pokazują, że wszystko zostało dokładnie zaplanowane w scenorysie (ujęcia, kadry klatkaż).

Film Cześć Tereska to obraz współczesno-obyczajowy, opowieść o samotności nastolatki $z$ warszawskiego blokowiska. Otwarcie tego filmu jest znacznie bogatsze filmowo od Matki swojej matki. Postanowiłem w nim połączyć materiały dokumentalne z inscenizowanymi. Punktem wyjścia jest Komunia Święta tytułowej Tereski. Piosenka śpiewana przez dzieci na tej uroczystości buduje i spina całą czołówkę. Łączy sceny - Komunii w kościele, ekspozycji blokowiska, leniwego życia na balkonach, zabaw dzieci na podwórku. Ideą tego układu jest pokazanie świata Tereski, jej korzeni: Kościół, blokowisko, rodzice, agresja dzieci. Na tym tle rozgrywać się będzie akcja filmu. Zebrany materiał został ułożony w montażu. Fragment scenariusza i szkice tego otwarcia przedstawia ilustracja 15.

Rozwiązań na tzw. „otwarcie”, czyli początek filmu mogą być tysiące, ale najważniejsze, by problem „jak zacząć” sobie postawić wcześniej, a nie po zdjęciach (co często się zdarza), gdy czołówkę kleci się z odpadów. 

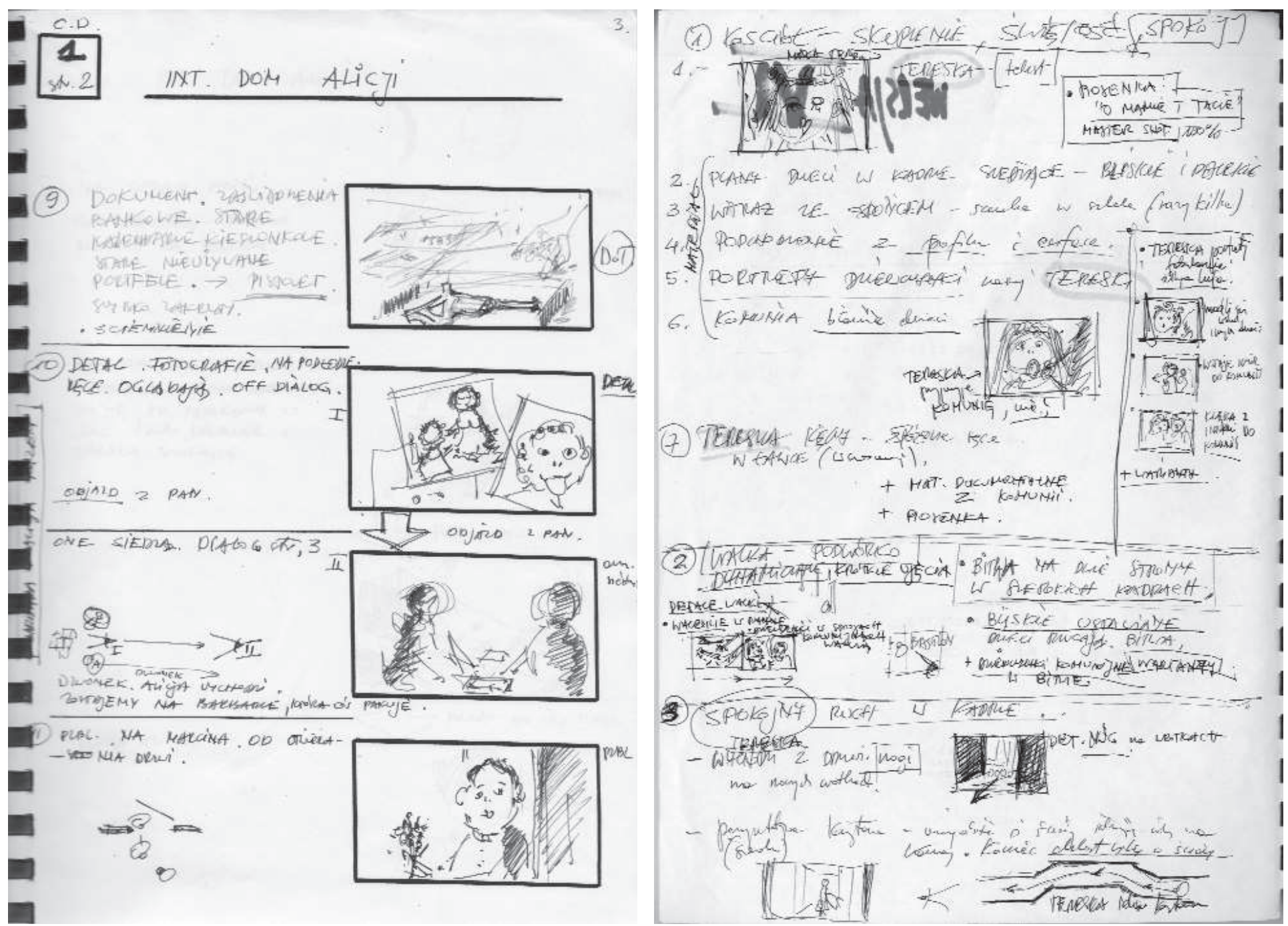

Ilustracje 14 i 15

\section{ZAKOŃCZENIE}

Jak zaplanować scenę końcową filmu? Odpowiedź jest jedna PRECYZYJNIE!

Finał filmu bardzo często jest problemem. Albo jest za długi albo za krótki. Albo powtarza to, o czym już mówiliśmy (problem kilku zakończeń). Albo coś rozpoczyna, a przecież powinniśmy już kończyć... Dlatego uważam, że zakończenie filmu powinno być bardzo dokładnie przemyślane i najlepiej, żeby było maksymalnie proste.

Spójrzmy na dwa przykłady:

Niedzielne igraszki (il.16) - scena końcowa została starannie rozrysowana. Składa się z dwóch prostych ujęć. Pomysł sceny polega na zderzeniu czerni i bieli: bohater - gruby Józek - wybiega z ciemności (czarna brama), idzie ku świetlanej przyszłości (jasna brama), nad którą czuwa Stalin. Józek przebiega obok dzieci, które są niezdarnie musztrowane przez małego chłopca. To dzielni następcy bohatera filmu. Scena została skręcona tak, jak została rozrysowana. W trakcie zdjęć nie uważałem, aby wymagała korekt albo dodatkowych elementów. Potem doszła muzyka - wojskowy marsz pełen radosnego optymizmu, który podbił ironiczny charakter zakończenia. 
Cześć Tereska (il.17) - mimo, że cały film jest skomponowany luźno, a wiele scen ma paradokumentalny charakter, zakończenie zostało precyzyjnie zaplanowane. Tereska po skatowaniu Edzia wraca do swojego bloku mieszkalnego i w drzwiach wejściowych na klatkę schodową, mija się z dziewczynką na wrotkach (taką jaką była kiedyś). Dziewczynka pozdrawia ją obojętnym „Cześć Tereska!”. To zakończenie podkreśla jeden z problemów filmu - samotność bohaterki, obojętność świata, w jakim żyje.

Warto tu także zwrócić uwagę na rozwiązanie pewnego ważnego problemu reżyserskiego tzw. styku scen. Cięcie między scenami w filmie może mieć kolosalne znaczenie myślowe, narracyjne, rytmiczne. „Na cięciu” rodzą się znaczenia, upływy czasu, pointy. Dlatego warto czasem pomyśleć twórczo o „stykach”.

Wróćmy zatem do zakończenia Cześć Tereska i przyjrzyjmy się stykowi dwóch ostatnich scen filmu. Scena wcześniejsza kończy się biologicznym dyszeniem bohaterki w bliskim planie. Następuje cięcie i nowa scena (ostatnia scena filmu) zaczyna się detalem idących nóg (samotnych!) bohaterki. Zachowana jest płynność montażowa, jednocześnie następuje skok czasowy (noc w dzień), a także ogromny skok znaczeniowy - teraz opowiadam o alienacji Tereski.

Ilustracje 16 i 17
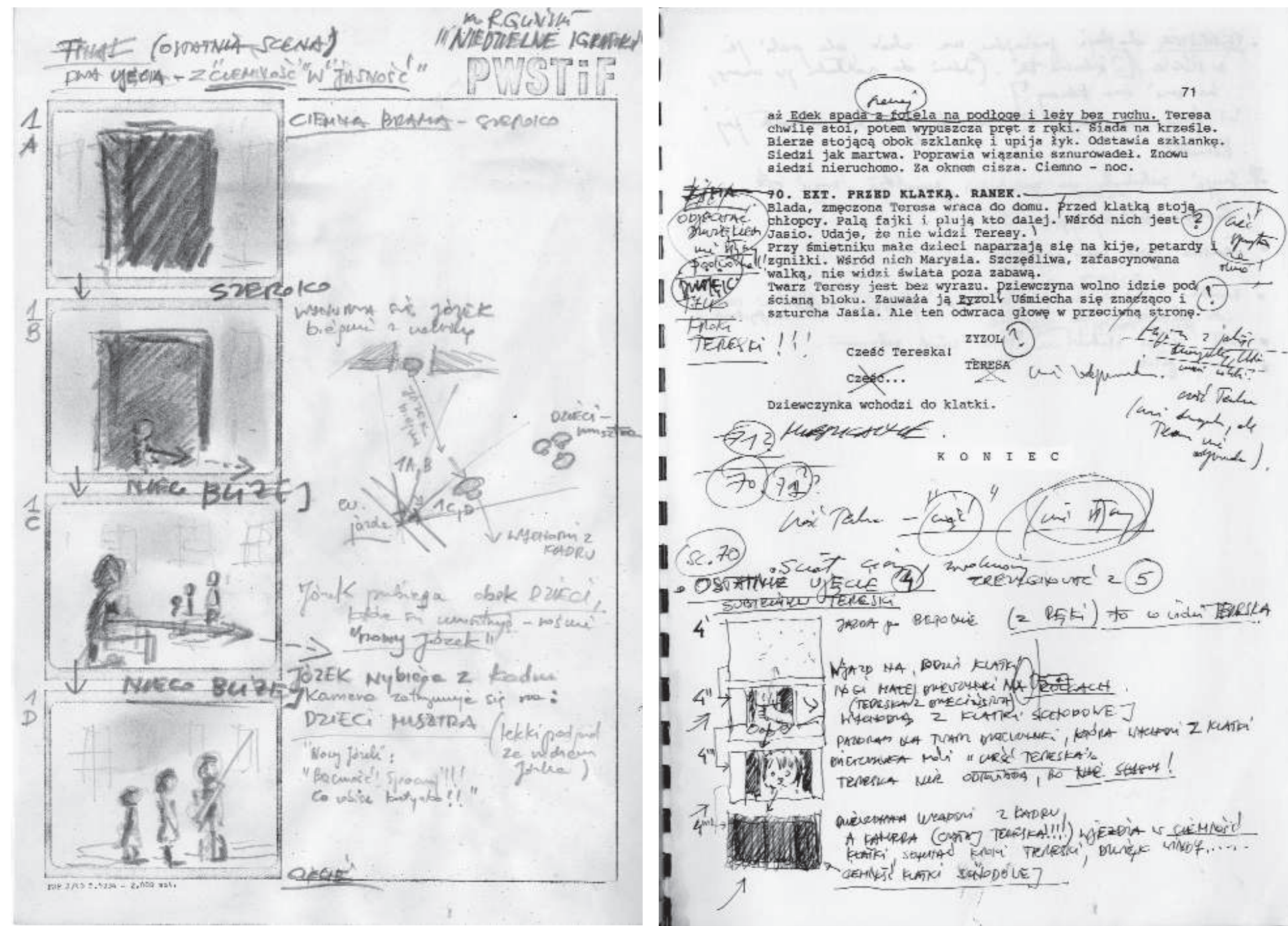
D. OBSADA

Wybór aktora to niezwykle ważny moment dla reżysera. Decyduje o powodzeniu lub klęsce filmu. Jak wybrać aktorów?

„Są dwa momenty w których reżyser musi mieć natchnienie: kiedy wybiera temat i kiedy wybiera aktorów. Reszta jest wykonaniem, przypomina piłowanie laubzegą" - powiedział kiedyś Andrzej Wajda.

Bergman pisząc scenariusz widzi konkretnego aktora, wyobraża sobie jego głos, gest, zachowanie. Postać, jaką tworzy w scenariuszu, jest całkowicie zespolona $\mathrm{z}$ wybranym przez niego wcześniej aktorem.

Robert Bresson szukał do swoich filmów „modeli, co mają duszę i ciało niepowtarzalne”. Chciał zobaczyć w aktorze to: „... co może on z siebie dać najrzadziej spotykanego i tajemnego".

Eisenstein lansował teorię typażu, czyli doboru aktora przede wszystkim ze względu na jego warunki zewnętrzne, odpowiadające idealnie „typowi” wyobrażonej przez niego postaci.

Podobnie postępował Roberto Rossellini: „Wybieram aktorów wyłącznie ze względu na ich warunki fizyczne”. Korzystał z aktorówamatorów, często zmieniał scenariusz i dialogi stosownie do ich gry i możliwości.

Fellini: „...postać dla mnie musi się zgadzać z aktorem. Szukam twarzy, które mówią wszystko o sobie przy pierwszym pojawieniu się na ekranie. [...] Wybieram aktora do postaci, którą mam na myśli. Wiele zależy od twarzy, jaką mam przed sobą, od tego, co mi ona mówi, od tego także, co mi pozwala odczuć, zrozumieć, odgadnąć”.

Z powyższych poglądów wyłaniają się trzy podstawowe sposoby wyboru aktorów:

a. według postaci, czyli według warunków zewnętrznych aktora,

b. na kontrze do postaci, czyli warunki zewnętrzne są nieważne, istotna jest osobowość aktora

c. maksymalna prawda, czyli wybór aktora nieprofesjonalnego, tak zwanego „naturszczyka”.

Na pozór pierwsza metoda wydaje się prymitywna. Jeśli postać zapisana $\mathrm{w}$ scenariuszu jest gangsterem-zabijaką i reżyser wybierze dużego mięśniaka o kwadratowej szczęce, to taki wybór będzie banalny. Może się jednak okazać, że w filmie osiłek ma momenty słabości, w których przemienia się w naiwną owieczkę. Wtedy widzimy, jak decyzja reżysera nabiera wartości. Fellini obsadził bohaterów La Strady po postaci. I film i oni są wspaniali.

Druga metoda jest trudniejsza. Trzeba dotrzeć do aktora, a właściwie do człowieka. Poznać go i zobaczyć, czy to, co ma w sobie, przerzuci się na ekran. W scenariuszu Absolwenta tytułowa postać to przystojny, wysoki student college’u, grający w koszykówkę w lokalnej drużynie. Mike Nichols wybrał do tej roli aktora małego, niepozornego, nikomu nieznanego, który zachwycił go na próbnych zdjęciach swoją wyobraźnią, inteligencją i humorem. Ten aktor nazywał się Dustin Hoffman.

Obsadzanie aktorami niezawodowymi jest bardzo kuszące, ponieważ wydaje się nam, że naturszczyk przyniesie postaci prawdę, 
której nie osiągniemy innymi środkami. Jeżeli znajdziemy kogoś, kto w życiu zachowuje się podobnie, jak nasza postać ze scenariusza, jesteśmy pewni, że złapaliśmy złotą rybkę. Nic bardziej złudnego. Po pierwsze amator nigdy nie pójdzie w głąb postaci. Zawsze będzie się ślizgał po powierzchni, po małych prawdach prostych zachowań. Nie zbuduje tajemnicy, drugiego dna, dodatkowego kontekstu psychologicznego. Po drugie trzeba się liczyć, że amator jest nieobliczalny. Jednego dnia jest prawdziwy, a następnego, przy innej scenie, zaczyna fałszować. Po trzecie nie kontroluje ekspresji, nie trzyma pozycji, zapomina o intencjach, a więc, np. wykonanie długiego, skomplikowanego ujęcia $\mathrm{z}$ amatorem jest prawie niemożliwe.

W mojej praktyce reżyserskiej zdarzyło mi się obsadzać główne role według każdego klucza: według postaci, na kontrze i według maksymalnej prawdy.

W pierwszym przypadku (np. Grubego Józka w Niedzielnych igraszkach zagrał gruby i silny chłopak) starałem się zawsze odnaleźć w postaci coś zaskakującego, ukrytego pod oczywistą fizycznością.

W drugim przypadku (np. silną, walczącą Olę Watową w moim filmie Wszystko co najważniejsze zagrała aktorka wątła, mała, chuda) trzeba postępować podobnie - powoli w trakcie akcji filmu odsłaniać cechy postaci, które są schowane pod „kontrowymi” warunkami zewnętrznymi.

Na trzeci przypadek decydowałem się, kiedy nie miałem wyjścia. Na przykład, gdy bohaterami były dzieci (Niedzielne igraszki) albo nastolatkowie (Cześć Tereska). Praca $\mathrm{z}$ amatorami jest mordęgą. Po pierwszych zachwytach prawdą i naturalnością, pojawia się nuda. Amator jest taki sam w kolejnych scenach. Dlatego chciałem zawsze wycisnąć z „naturszczyka” coś więcej. I coś nowego. Wtedy zaczynała się Golgota.

Powyższe uwagi dotyczą ról pierwszoplanowych. W przypadku epizodów zasada jest jedna. Muszą być soczyste i wystarczająco silne, by przyciągnąć uwagę widza. Powierzam je więc aktorom wyrazistym, o dużej osobowości lub o charakterystycznym wyglądzie. Wtedy wiem, że taki aktor się „przerzuci”. Może to być aktor zawodowy lub naturszczyk - obojętne. Ważne, by widz go zauważył i zapamiętał.

Takim aktorem był Henryk Bista. Stworzył w polskim kinie (zresztą nie tylko w polskim, bo także w Liście Schindlera Spielberga) niezliczoną ilość wyrazistych epizodów. Bista, z małej rólki, z jednej sceny, z dwóch zdań dialogu potrafił stworzyć pyszną, charakterystyczną postać, którą długo pamiętaliśmy po wyjściu z kina. Nie ma małych ról, są tylko mali aktorzy!

Wyrazistym naturszczykiem był Jan Himilsbach. Zachrypnięty głos, charakterystyczna sylwetka i cięte, inteligentne dialogi (najczęściej pisał je sobie sam) pozwoliły mu stworzyć w polskim kinie całą gamę barwnych epizodów, które bywały latami cytowane w anegdotach. 
Bardzo częstym sposobem na obsadzanie aktorów są zdjęcia próbne. Stosuje się je najczęściej, gdy reżyser chce wybrać aktorów o nieznanych twarzach, ale także i wtedy, gdy nie może się zdecydować na wybór z kilku, jego zdaniem równorzędnych, kandydatur.

Próbne zdjęcia to koszmar - i dla aktora, i dla reżysera. Dla aktora, bo jest postawiony w pozycji zdającego egzamin, gdzie sprawdza się jego wygląd oraz zdolności zawodowe. Dla reżysera, bo mimowolnie staje się kontrolerem, egzaminatorem. Jeden i drugi, reżyser i aktor, odczuwają jednocześnie skrępowanie i bezsensowność całego wydarzenia, bo jak można wybadać zdolności aktora i poznać jego osobowość w trakcie półgodzinnego spotkania. Niestety, nie wymyślono nic lepszego. Próbne zdjęcia stosuje się wszędzie: w Hollywood i w amerykańskim kinie niezależnym, w kinematografiach europejskich i azjatyckich. Gdy szuka się odtwórcy głównego bohatera, gdy szuka się obsady do epizodów, gdy szuka się młodej nieznanej twarzy, gdy szuka się aktorów niezawodowych.

Mam za sobą maratony zdjęć próbnych. Wspólnie $\mathrm{z}$ asystentami stosowaliśmy różne metody. Wiem jedno, nie ma dobrej recepty, jak robić zdjęcia próbne. Pamiętajmy, to pierwszy kontakt $\mathrm{z}$ aktorami, czyli ludźmi chwiejnymi w nastrojach, kapryśnymi, naiwnymi, a także wrażliwymi (zwłaszcza na swoim punkcie). Jednocześnie znajdującymi się w sytuacji stresowej, bo przyszli na jakiś upiorny egzamin. Większość ma poczucie absurdalności tego spotkania, niemniej decydują się na ten szaleńczy krok w nadziei, że dostaną rolę. Czy w takiej sytuacji aktor może zagrać coś sensownego? Oczywiście, że nie. Dlatego uważam, że do każdego aktora trzeba podejść indywidualnie. Znaleźć sposób na niego. Nie ma nic gorszego jak zdjęcia próbne, które przypominają fabryczny taśmociąg, na którym podjeżdżają aktorzy do obróbki. Imię, nazwisko, scenka, następny. Aktor jest skołowany, odczuwa niesmak i niechęć do filmu. Reżyser zaś nie wie nic. No może tylko tyle, że „przerobił” w ciągu dnia czterdziestu aktorów i żadnego nie pamięta.

Pierwszy moment zetknięcia $\mathrm{z}$ aktorem na zdjęciach próbnych jest bardzo ważny. Staram się zanotować pierwsze wrażenie, jakie na mnie zrobił, co wniósł ze sobą, jaki nastrój, jakie fluidy płyną od niego. Staram się zauważyć to coś, co iskrzy od aktora.

Potem próbuję go oswoić i otworzyć. I zdobyć odrobinę zaufania. Pytam, co robił do tej pory, co grał, co chciałby grać, jakie ma marzenia i plany. Pytam o inne rzeczy - co mi przyjdzie do głowy. Nie ma najmniejszego znaczenia, co aktor odpowiada. Ważne, że mówi o sobie, a aktorzy lubią o sobie opowiadać. Wtedy przypatruję mu się uważnie, patrzę jak wygląda, jak mówi, jakie wykonuje gesty. Czasem nagle mu przerywam i mówię, by coś wykonał. Na przykład, panie proszę o zmycie makijażu, bo zazwyczaj mają kilogramy make up-u na twarzy. Panów proszę o zdjęcie marynarki. Albo proszę ich, by opowiedzieli dowcip. Albo anegdotę z teatru. Po co? Chcę wybić ich z rytmu gadania i zobaczyć ich naturalną re- 
akcję na zaskoczenie. Najczęściej bywa ona pretekstem do dalszej rozmowy.

Ten etap to delikatne badanie. Albo, używając terminologii lekarskiej, oględziny. Teraz trzeba przejść do wiwisekcji. Pytam o scenkę, której tekst aktor dostał wczoraj. Albo dziesięć minut temu. Nie ma to znaczenia, bo przecież nie będę go egzaminował z dialogu scenki. Chcę tylko usłyszeć jak myśli, zobaczyć jaką ma wyobraźnię. Może odczytał scenkę inaczej. Może czymś mnie zaskoczy. Scenka zazwyczaj pochodzi ze scenariusza filmu, więc zawsze mam nadzieję, że rozmowa odkryje coś, czego nie wiem.

Potem proszę, by zagrał fragment razem z partnerem. Niczego nie sugeruję, niczego nie narzucam. Żadnej interpretacji. Chcę zobaczyć subiektywne spojrzenie aktorów na ten kawałek tekstu. Często aktorzy starają się powiedzieć dialog ze scenki litera po literze i na tym skupia się ich cała uwaga. Nic gorszego. Zabieram im tekst i proszę, by improwizowali. Nieważne są słowa, ale intencje, jakie niosą postacie przez nich grane.

Następnie bawimy się w warianty. Zmieniamy intencje. Szukamy wspólnie nowych pomysłów na postacie ze scenki. Czasem miłość przerabiamy na nienawiść, zabawę na tragedię, a komedię na melodramat.

Niektóre z tych wariantów notuję kamerą video. Spokojną, ze statywu, uważnie obserwującą twarz aktora, rzadziej jego sylwetkę.

Tak kończę pierwszy etap zdjęć próbnych.

Jeśli coś mnie poruszy, zainteresuje w aktorze zapraszam go ponownie. Kilka dni przed spotkaniem aktor dostaje tekst sceny, którą miałby ewentualnie grać w filmie i proszę, by nauczył się jej na pamięć.

$\mathrm{W}$ czasie następnej tury zdjęć próbnych staram się $\mathrm{z}$ aktora stworzyć postać, która istnieje w scenariuszu. Przygotowuję fragmenty kostiumu, które odpowiadają filmowej postaci, często też zapraszam charakteryzatorkę. Aktor gra całą scenę, bez improwizacji, tak jak by to miało miejsce $\mathrm{w}$ filmie. Kręcę tę scenę $\mathrm{z}$ jednego ustawienia jednym długim ujęciem w planie bliskim - chcę zobaczyć twarz, czy niesie prawdę, jakie przenosi emocje. Dubel robię w planie szerszym, chcę zobaczyć, jak aktor się rusza, jaką ma dynamikę gestów, jak chodzi. Zostaję z tym nagraniem na kolejne dni i noce. Oglądam wielokrotnie. Porównuję z innymi kandydatami. Czasem się decyduję. Czasem nie. Wtedy zapraszam aktora jeszcze raz. Inne sceny, nowe warianty. Staram się zderzyć kandydata $\mathrm{z}$ aktorami, którzy już zostali obsadzeni. Obserwuję, co rodzi się pomiędzy nimi.

Próbne zdjęcia to długi i żmudny proces. Nie można ich zignorować, bo one pomagają podjąć najważniejszą decyzję - kto gra w moim filmie?

Zdjęcia próbne dla aktorów nieprofesjonalnych wymagają jeszcze większego nakładu pracy. Po pierwsze musimy obejrzeć więcej kandydatur, ponieważ na początku nie wiemy nic. Aktorów zawodowych znamy pobieżnie z teatru, z telewizji, ktoś-coś o nich słyszał, 
agent dostarczył nam wcześniej ich dossier i fotografie. Gdy szukamy naturszczyka do filmu, poruszamy się jak ślepiec we mgle.

$\mathrm{Na}$ dodatek materia jest bardzo delikatnej natury. Aktor zawodowy, przynajmniej teoretycznie, wie jak wygląda kamera, studio, praca nad sceną. Naturszczyk nie wie nic. Najczęściej boi się. A nie można go spłoszyć, bo będzie sztuczny. Przecież szukamy prawdy jego zachowań.

$\mathrm{Z}$ tych powodów pierwszy etap zdjęć próbnych z naturszczykami staram się robić w ich środowisku naturalnym. Na przykład w szkole (gdy szukam ludzi młodych) albo we własnym mieszkaniu kandydata, gdzie czuje się on w miarę swobodnie. Do rejestracji używam małej, jak najmniejszej, kamery video, żeby go nie paraliżować.

Daję wtedy kandydatom proste zadania dramaturgiczne typu kłótnia lub prośba. Na przykład scenka dwójkowa: miałeś w szufladzie paczkę papierosów, Marek zabrał ci ją i wypalił. Marek nie chce się przyznać, udaje, że nic nie wie o żadnych papierosach. Masz wymusić na Marku przyznanie się do winy oraz zwrot papierosów. Cała scenka własnymi słowami. Jedna postać oskarża, druga udaje niewiniątko. Daję znak do rozpoczęcia. Niezauważalnie włączam kamerę. Zazwyczaj początek jest niemrawy. Potem jednak napięcie rośnie. Kandydaci ładują się nawzajem, są coraz bardziej prawdziwi. Zdarza się, że zapominają o mnie i kamerze.

Pamiętam dwie dziewczyny z domu dziecka, które robiły scenkę kłótni o papierosy. Bardzo wciągnęły się w rolę. Zrobiły się czerwone, spocone i po chwili zaczęły się bić. Trudno było je rozdzielić.

Często proszę, by kandydaci zamieniali się rolami. Ten agresywny ma być spokojny i odwrotnie. Wymyślamy inne pointy scenki. Albo inny początek. Wszystko po to, bym mógł zobaczyć, czy oprócz prawdy kandydat ma odrobinę wyobraźni.

Następny etap, do którego zapraszam osoby wybrane z castingów na mieście, odbywa się w miejscu neutralnym, najczęściej w studiu filmowym.

Naturszczyk dostaje tekst dialogu do nauczenia. Ma zagrać go (często z partnerem profesjonalnym) przed kamerą, w ciszy, w sztucznym oświetleniu reflektorów. Zazwyczaj kończy się to niepowodzeniem. Człowiek wyrwany $\mathrm{z}$ własnego środowiska jest skrępowany, zachowuje się sztucznie, coś udaje. Na dodatek ma mówić narzuconym mu dialogiem. Skutki są fatalne. Naturszczyk stara się powiedzieć dokładnie to, co zostało napisane. Klepie bezrozumnie i nieprawdziwie. Wtedy staram się odnaleźć jego prawdę. Zmieniamy tekst. Przechodzimy na metodę „własnymi słowami”. Uspokajamy scenę. Mniej ruchu, więcej kontaktu z partnerem. Albo odwrotnie, więcej ruchu i rekwizyt, który narzuca czynność fizyczną. Wszystko po to, by odnaleźć zagubioną prawdę amatora.

Zdjęcia próbne $\mathrm{z}$ amatorami wymagają czasu i cierpliwości. Do filmu Cześć Tereska szukałem odtwórczyni głównej roli ponad rok. Razem $\mathrm{z}$ asystentami przemierzaliśmy szkoły, młodzieżowe kółka 
teatralne, domy dziecka, poprawczaki. Obejrzeliśmy tysiące kandydatek. Po roku miałem „bank” kilkunastu Teresek. Z każdej sesji zostawała jedną, dwie. Teraz trzeba było wybrać. Robiłem kolejne próby. Zderzałem potencjalną Tereskę $\mathrm{z}$ aktorami zawodowymi. Chciałem zobaczyć, jak Tereska prezentuje się z Ojcem i Matką, które to role zostały wcześniej obsadzone. W końcu podjąłem decyzję.

Wybrałem dziewczynę, która:

- nosiła w sobie mój wizerunek postaci Tereski ze scenariusza

- była naturalna przed kamerą, nie grała, a „była”

- wchodziła jak w masło w sytuacje wymyślone

- miała w sobie tajemnicę, przez wiele spotkań nie mogłem odgadnąć, jaka jest, co w niej siedzi.

Teraz myślę, że Tereska została wybrana według wszystkich trzech metod: według postaci (tak ją sobie wyobrażałem), według osobowości (niosła ze sobą tajemnicę, a także zło, jak się później okazało), według prawdy (była bardzo prawdziwym naturszczykiem).

Kształt sceny dialogowej, a co za tym idzie budowa master shotu, wynika $\mathrm{z}$ pracy $\mathrm{z}$ aktorem. Tu dotykamy podstawowego założenia filmowych prac przygotowawczych. Mianowicie, podstawowy etap pracy $\mathrm{z}$ aktorem powinien odbywać się przed kręceniem filmu.

Tylko wtedy, wybrany aktor może miękko wejść w świat swojej postaci. Przed zdjęciami musi odpowiedzieć sobie na wiele pytań, rozwiać wątpliwości i poczuć rolę. Musi wiedzieć „jak grać?”.

Powinien wtedy stworzyć rysunek postaci, a także poznać przebieg zmian, jakie będą jej udziałem przez cały film. W trakcie zdjęć pracuje się na wyrywki, kręci sceny nie chronologicznie. Aktor i reżyser muszą być do tego przygotowani. W każdym momencie muszą też potrafić złożyć te poszatkowane fragmenty w harmonijną całość.

Dlatego na kilka tygodni (sic!) przed rozpoczęciem zdjęć należy zacząć próby z aktorami: Najpierw stolikowe - żeby wytłumaczyć aktorom w czym grają. Wysłuchać ich sądów, krytyki czy propozycji. Przeanalizować postacie, określić zadania aktorskie. Potem sytuacyjne - żeby zbudować sceny. Znaleźć sposoby realizacji tego, co wymyślone teoretycznie. Zbudować więzi między bohaterami, opracować przebiegi zmian w postaciach, napięcia, dialog. Skomponować działanie fizyczne, wprowadzić ruch. Wtedy można przekonać się, czy to co wymyślone w scenariuszu ma siłę. Czy klei się z aktorem?

Zwyczaj robienia prób aktorskich przed zdjęciami jest bardzo rozpowszechniony w Stanach Zjednoczonych, gdzie 3/4 reżyserów robi próby i w ten sposób przygotowuje siebie oraz aktorów do zdjęć.

Oglądałem w Nowym Yorku próby Sydneya Lumeta do filmu Garbo talks. Zaczęło się jak w teatrze, przy stoliku od omówienia idei filmu i koncepcji postaci, a skończyło na stworzeniu sytuacji do wszystkich scen dialogowych. Zostały one potem przeniesione na plan zdjęciowy. Jak? Gdy Lumet akceptował scenę, asystenci fiksowa-

E. PRACA Z AKTOREM 
li ustawienia aktorów przy pomocy kolorowych plastrów. Potem mierzyli odległości pomiędzy plastrami i całą choreografię ruchów oraz zatrzymań aktora zaznaczali na planie sytuacyjnym. Taki rysunek dostawał operator. Wspólnie z Lumetem dorysowywali ustawienia kamer i ich ruch. Przed rozpoczęciem zdjęć każda scena dialogowa miała przygotowany rysunek rzutu ustawień aktorów i kamery. Każdy pion realizacyjny ekipy dostawał ten rzut - wszyscy wiedzieli, co i jak będzie kręcone. W trakcie zdjęć, gdy aktorzy wchodzili do obiektu zdjęciowego, czekały na nich już zaznaczone pozycje zatrzymań i linie przejść. Używali tych samych kolorowych plastrów, co na próbach. Potem w czasie kręcenia, niektóre pozycje aktorów i ustawienia kamery oczywiście ulegały korektom, ale zasada, czyli kręgosłup sceny, zostawał ten sam.

Dlaczego polscy reżyserzy unikają prób? Nie wiem. Próby są po to, by uniknąć nieporozumień na planie zdjęciowym. By poznać i przygotować aktora, osadzić go w postaci. By nie zaczynać wszystkiego od zera, bo wtedy nie można iść w głąb i w trakcie zdjęć walczy się jedynie z czasem, by cokolwiek zarejestrować. W czasie prób można pozwolić sobie na poszukiwania i na błądzenie. Praca $\mathrm{z}$ aktorem niesie ze sobą sytuacje stresowe, czasami pojawia się kryzys. Nie wiadomo dokąd iść, jak dalej budować postać i cały film. Próby dają czas na zastanowienie, na wyjście z kryzysu.

Istnieje pogląd, że próby zabijają spontaniczność i prawdę. Że aktor, zwłaszcza niezawodowy, będzie rutynowo klepał. Nic bardziej fałszywego. Próby są potrzebne każdemu aktorowi, a szczególnie niezawodowemu. Żeby organicznie zrósł się ze sceną, a przede wszystkim, żeby nauczył się dialogu. Nie ma nic gorszego, jak aktor „haftujący", czyli usiłujący sobie w czasie ujęcia przypomnieć, co mówi. Aktor niezawodowy musi znać dialog na tzw. stuprocentową „pamkę”. Jeśli nie wie, co ma powiedzieć, to paraliżuje go strach. Zamiast prawdy, ma obłęd w oczach.

Dlatego zawsze, gdy mam do czynienia $\mathrm{z}$ aktorem nieprofesjonalnym, katuję go dialogiem. By znał go jak pacierz. Gdy dialog siedzi już w nim głęboko, gdzieś w podświadomości, wtedy można przystąpić do zabawy w improwizacje, w warianty, tworzyć dodatkową "piankę" na postaci.

Przed rozpoczęciem zdjęć do Cześć Tereska przez kilka tygodni próbowaliśmy sceny Tereski z Edziem, którego grał Zbyszek Zamachowski. Tereskę grała 15-letnia dziewczyna, która nigdy nie stała przed kamerą. Podstawowy problem, jaki musiałem rozwiązać w tych próbach, to połączenie dwóch różnych konwencji grania: aktora zawodowego z amatorem. Zamachowski grał - prowadził napięcie, trzymał pauzy, dawkował ekspresję. Tereska po prostu była - nie grała. Z jednej strony musiałem „zdjąć” ze Zbyszka granie, $\mathrm{z}$ drugiej strony musiałem nauczyć Tereskę słuchania partnera i reagowania na niego. A także podstawowych elementów techniki - jak trzymanie pozycji i powtarzanie sceny. 
Drugim ważnym zagadnieniem, które należało skorygować w czasie prób do Cześć Tereska, był dialog. Aktor zawodowy zazwyczaj „układa się" do dialogu zapisanego w scenariuszu. Chociaż bywają kwestie, które nie leżą aktorowi i brzmią w jego ustach nienaturalnie. Trzeba je wtedy zmienić.

W przypadku aktora niezawodowego sprawa jest bardziej skomplikowana. Aktor ten musi mówić swoim językiem, bo innym nie potrafi. A jednocześnie musi przenieść napięcia i treść, które są w scenariuszu. Rozwiązanie jest jedno - cały dialog dla niezawodowca musi być pod niego napisany. W ścisłej współpracy z nim. Wnosi on wtedy do roli swoje słownictwo, swój świat pojęć, swoją osobowość.

Dialogi w scenach zaczepek i podrywu pomiędzy chłopcami a Renatką i Tereską w Cześć Tereska zostały wymyślone przez młodocianych aktorów. W scenariuszu oczywiście był dialog, który napisałem wspólnie z kolegą. Kompletnie nie sprawdzał się na próbach. Młodzi ludzie mówili sztucznie, klepali.

„Jak wy mówicie w takiej sytuacji?” - zadałem pytanie młodym aktorom. Padły propozycje. Zaczęliśmy obrabiać dialog, zachowując intencje i tematy ze scenariusza. Wyrażaliśmy je tylko innymi słowami. Powstała prawdziwa scena. Dodaliśmy ruch. Sposób sfotografowania tej sceny narodził się organicznie, po próbach. Założenie inscenizacyjne jest bardzo proste. Dziewczyny siedzą na ławce, chłopcy przychodzą na podwórko, siadają na ławce obok. Następuje wymiana zdań tzw. podwórkowy podryw. W finale sceny dziewczyny wstają z ławki i odchodzą. Cała akcja zanurzona jest w sosie ujęć dokumentalnych z życia tego podwórka.

$\mathrm{Na}$ czym polega praca $\mathrm{z}$ aktorem przed zdjęciami? Na stawianiu podstawowych pytań: kim jest film, jaki jest bohater? Na stworzeniu prawdziwej, wielowymiarowej postaci. Na dokładnej analizie scenariusza, wszystkich scen i sekwencji. Na zbudowaniu wiarygodnych scen dialogowych. Na poszukaniu środków wyrazu i emocji, które nadadzą postaciom rys oryginalności. A potem na ustawieniu scen, zorganizowaniu ruchu, zbudowaniu napięć i wydobyciu prawdy z sytuacji.

Dobra scena, $z$ harmonijnym rytmem i z dobrze wpasowanymi w nią postaciami może powstać tylko dzięki próbom. Wtedy reżyser ma czas, by szukać najlepszych wariantów ruchu. By powiązać ruch $\mathrm{z}$ emocjami aktora i z dialogiem. Zbadać proporcje pomiędzy wszystkimi elementami. Czasem zdarza się, że aktor i reżyser błądzą. Badają przecież różne możliwości rozwiązań. Przeżywają momenty załamań. Szukają i w końcu wychodzą ze ślepego zaułka. Po to są próby!

W swojej praktyce reżyserskiej zawsze je stosuję. Ku rozpaczy producenta, bo musi te próby zorganizować, a ku satysfakcji aktorów, bo dzięki próbom czują się pewniejsi. Chociaż zdarzały się wyjątki, że traktowali je jak moje fanaberie i starali się za wszelką cenę od nich wykręcić.

Początek mojej pracy jest oczywisty - omawiam bohatera, kim jest, jaki ma cel działania, gdzie tkwi konflikt i punkty zwrotne w ra- 
mach całego filmu. W podobny sposób opisuję inne postacie. Potem omawiamy poszczególne sceny, starając się odpowiedzieć na podstawowe pytania dotyczące granych przez aktorów postaci.

Po tym wstępie przechodzę do robienia sytuacji, czyli buduję w scenie ruch. Wyznaczam pozycje aktorów, tematy i kierunki ich działań. Szkicujemy z aktorami ruch, odnajdujemy motywacje, które skłoniły postacie do takiego, a nie innego działania.

Potem dodajemy do sceny dialog. Synchronizujemy go z ruchem. Dzielimy - te słowa przed czynnością, drugie na pauzie po ruchu, a jeszcze inne w jego trakcie. Wtedy zaczyna się rodzić scena...

Staram się ocenić czy wcześniej określone treści „przerzuciły się"? Czy są czytelne? Czy scena znaczy to, co miała znaczyć? Sprawdzam czy istnieje więź między postaciami, czy konflikt jest widoczny, czy wszystkie elementy dramaturgiczne zagrały?

Czasem aktor ma propozycję diametralnie różną od mojej. Jeśli uważam ją za lepszą, odrzucam swoją. Jeśli za gorszą, staram się nie urazić aktora i tłumaczę, dlaczego moje rozwiązanie jest lepsze. Gdy aktor nadal się upiera, proponuję kompromis - robimy warianty, czyli będę kręcić moje rozwiązanie, a potem także propozycję aktora. Mimo, że jestem jej przeciwny. Dlaczego? Bo do tanga trzeba dwojga. Nie mogę sobie pozwolić, by aktor się zbiesił, zamknął, usztywnił. A tak mogłoby się zdarzyć, gdybym wyrzucił jego propozycję do śmieci.

Gdy aktorzy znają już dialog na pamięć, proszę ich, by zagrali scenę w całości.

Wtedy mogę zbudować rytm - coś zwalniam, coś przyspieszam. Buduję proporcje między wszystkimi elementami. Niektóre pauzy wydłużam, inne skracam. Pewne znaczenia wydobywam, inne ukrywam, bo są zbyt wyraźne. To najważniejszy etap pracy. Do tej pory pracowałem wspólnie $\mathrm{z}$ aktorami. Teraz oni są po przeciwnej stronie, siedzą w postaciach.

I powoli tracą dystans do całości. Tylko ja mogę ocenić, czy coś trwa za długo lub za krótko, czy coś jest za mocne lub za słabe. Czy wszystko się czyta? A może niektóre elementy są zbyt oczywiste?

I znowu sprawdzam - czy scena ma prawdę? Czy postacie są wiarygodne? Czy aktorzy grają prawdziwie?

Jeżeli jestem zadowolony, nanoszę schemat sceny na rzut sytuacyjny. Zaznaczam na nim kierunki przejść i pozycje aktorów. Potem z operatorem rysuję do tego ustawienia i ruch kamery. Szkicujemy kadry. Scenorys master shota jest gotowy. Do tego trzeba jeszcze zaplanować ujęcia dodatkowe - przebitki.

Są wentylami bezpieczeństwa. W montażu, po ich użyciu można powrócić do tego samego master shotu. Albo do innego dubla. Pozwala to na przykład zmienić rytm sceny, podrzucić tempo, zaakcentować jednego lub drugiego bohatera. A nawet wyrzucić kawałek sceny. 
Kiedy studiowałem reżyserię w szkole filmowej, profesorowie NOTATNIK namawiali nas na prowadzenie notatnika reżysera. By notować w nim REŻYSERA własne i cudze pomysły na filmy, na sceny, na ujęcia. Początkowo tak jak moi koledzy, zignorowałem profesorskie porady. Miałem wszystko w głowie. A raczej wydawało mi się, że mam wszystko w głowie, że wszystko wiem. W trakcie realizacji etiud szkolnych okazało się jednak, że... nie wiem nic.

Potem zauważyłem, że faktycznie, wybitni „dorośli” reżyserzy ciągle coś notują i rysują. Zauważyłem, że Wajda na planie bez przerwy bazgroli, że Fellini szkicuje, a Hitchcock robi notatki. Okazało się, że to tylko małe uzupełnienia do tego, co zostało wykonane przed zdjęciami.

Okazało się, że przed zdjęciami ci wybitni reżyserzy robili masę przygotowań. Wynikiem tej pracy, a właściwie jej zapisem był zawsze: scenopis albo storyboard albo scenorys.

I tu dochodzimy do podstawowych pytań - JAK POWSTAJE ten zapis? Co wpływa na jego kształt? Jakie elementy decydują o jego treści i formie? A przede wszystkim - CO JEST CO? Czym różni się scenopis od storyboardu i od scenorysu? Jak każdy wygląda? Co jest lepsze?

Spróbujmy zdefiniować:

Scenariusz - zapis literacki treści filmu.

Scenopis - słowny opis rozbitego na ujęcia scenariusza, zawiera podział na ujęcia, wielkości planów, opisy ruchów kamery, metraż ujęć.

Storyboard - wizualizacja scenopisu. Przedstawia scenariusz rozbity na ujęcia, w postaci obrazków w formie kolejnych kadrów filmu. W scenopisie ujęcia są opisane, a w storyboardzie są narysowane. W ramce widzimy kompozycję kadru, wielkość planu, kierunek patrzenia albo ruchu.

Scenorys - polska nazwa storyboardu, czyli rozrysowanego scenopisu. Moim zdaniem jest pojęciem pojemniejszym niż storyboard. To rys sceny, czyli rozrysowana scena. Powinien zawierać rozrysowane kadry - obrazki ułożone w ciągu narracyjnym przewidującym przebieg ujęć w gotowym filmie (tak jak w storyboardzie). Ale nie tylko!

Scenorys powinien zawierać rzut pokazujący ustawienia kamery i jej ruch. Albo inne rysunki, które wyjaśniają, jak reżyser planuje wykonanie ujęcia. Bo scenorys to rysunek albo rysunki sceny rozbitej na ujęcia. Zawiera informacje dotyczące sposobu kręcenia sceny, a nie tylko efekt końcowy (storyboardowy układ kadrów).

Storyboard komputerowy zwany czasem animatik - ruchomy storyboard wykonany przy pomocy programu komputerowego. Pozwala animować ruch w storyboardzie. Polega to na tym, że w ramce kadru postać (rysunek albo fotografia) wykonuje ruch, taki sam jak w przyszłości aktor na ekranie. Kadr też może się poruszać - mamy wtedy złudzenie jazdy albo panoramy. Moim zdaniem animatik, mi- 
d.c. sc. 39

- sitar va líph - sing.

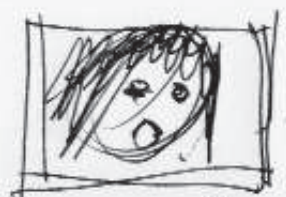

ZBU ZEATE

Tanequi

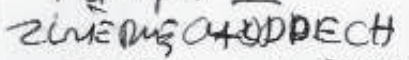

ZMSClOAA DYSW

- EDió caly - ray:-

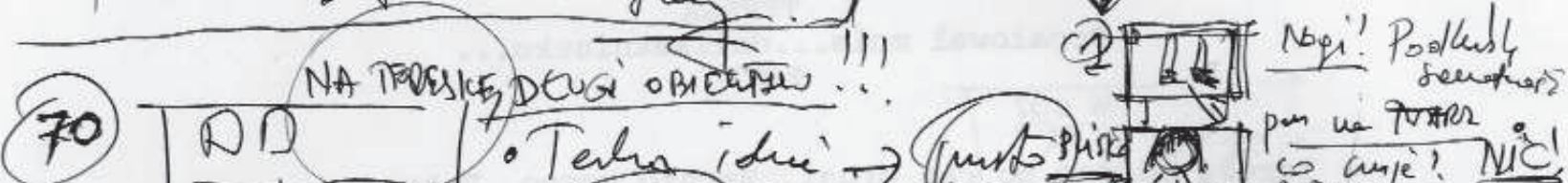

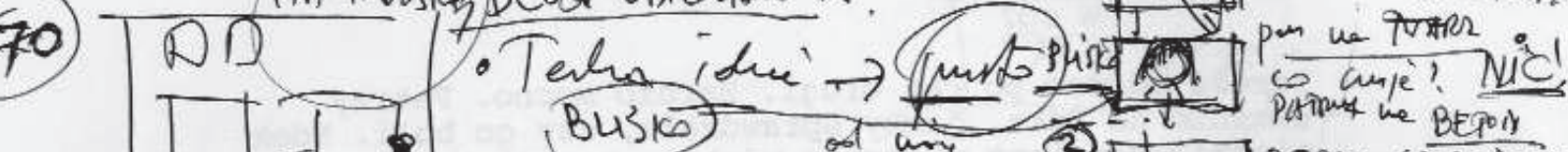

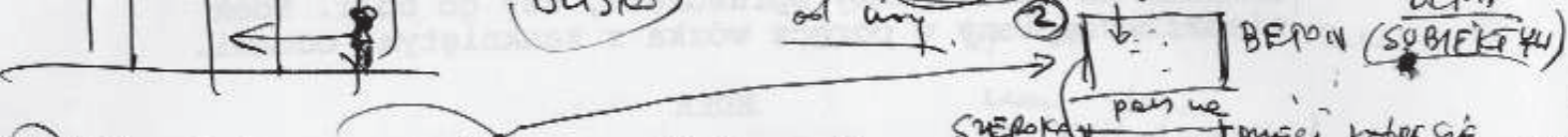

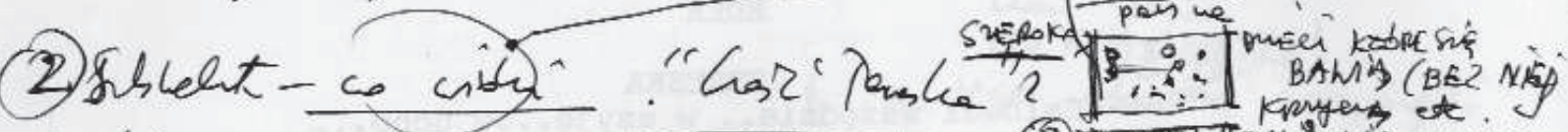

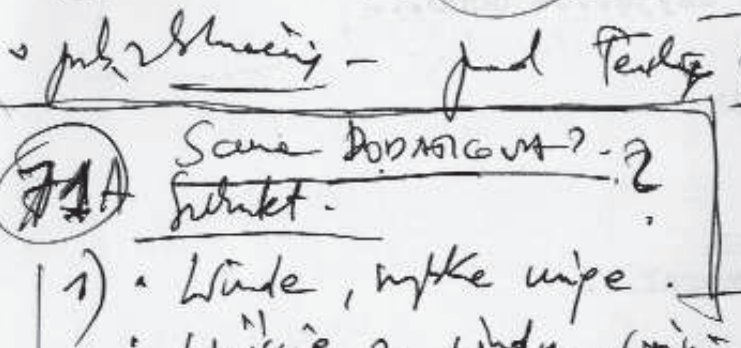

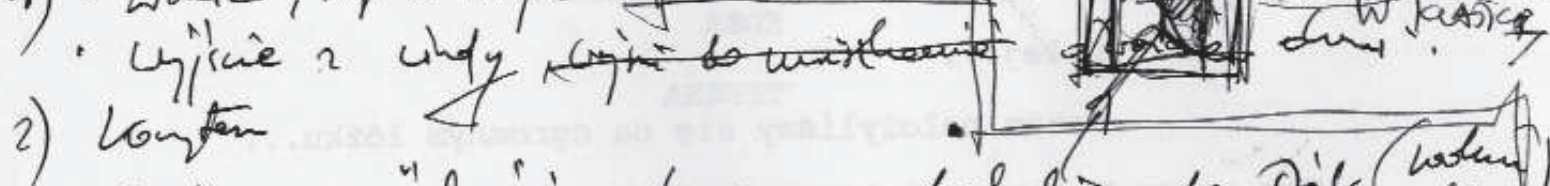

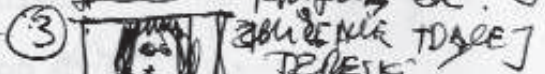

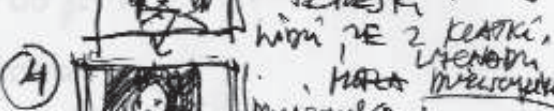

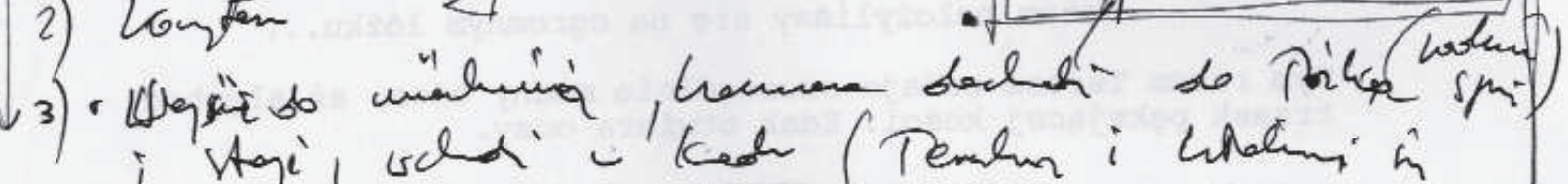

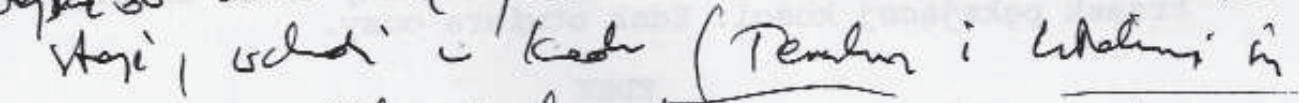

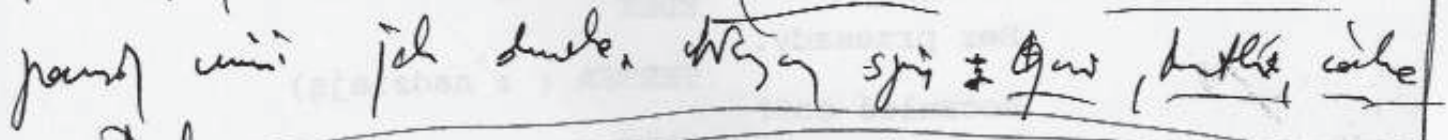
u Poh

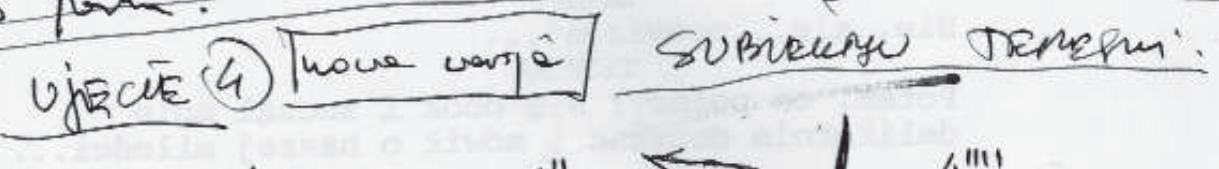

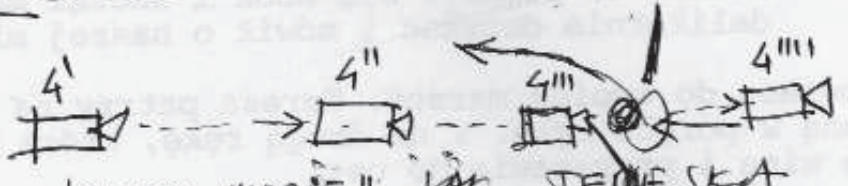

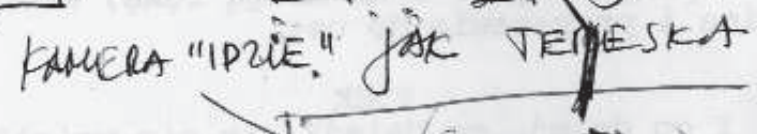


mo, że czasem do złudzenia przypomina, a raczej zapowiada, przyszłe ujęcie, ma w sobie coś sztucznego. Mam wrażenie, że animatikowe ujęcie wymyślił komputer, a nie człowiek. Nie widać w nim poszukiwań i wahań reżysera, nie widać mozołu dochodzenia do najlepszego kadru czy pomysłu na najlepsze miejsce dla kamery. Widać rezultat syntezę ujęcia, ale nie widać sposobu czy metody jego realizacji.

Uważam, że z wyżej wspomnianych metod zapisu scenorys daje najwięcej możliwości twórczych dla reżysera. Jest najpełniejszy! Najbogatszy! Mimo, że czasem szkicowy, daje dokładniejszy obraz przyszłego filmu niż scenopis, storyboard lub animatik!!! Scenorys to swoisty notatnik reżysera zapisany w trakcie prac przygotowawczych przed kręceniem filmu. Jest wynikiem bardzo istotnego (!!!) procesu twórczego, który występuje przed wejściem na plan zdjęciowy. Ten zbiór notatek z podróży pod hasłem „szukanie koncepcji wizualnej” filmu, najpełniej obrazuje metodę, jaką chce przyjąć reżyser, by nakręcić scenę, sekwencję czy cały film.

W dawnym kinie europejskim także wszyscy rysowali. Rysowali Eisenstein, Fellini i Passolini, Buñuel i Tarkowski.

Mniej więcej na początku lat sześćdziesiątych francuska Nowa Fala wywołała kryzys scenorysu. Ktoś określił storyboard kagańcem dla kamery. „Kamera jest wolna i może kręcić wszystko” - ta dewiza wniosła do kina bylejakość. Nowofalowa „prawda chwili” polegała zazwyczaj na byle jakim planie, byle jakim ruchu kamery, byle jakiej inscenizacji. Co prawda papież nowofalowców Jean-Luc Godard używał zawsze scenorysów, ale była to czarna owca w grupie wyznawców wyzwolonego kina autorskiego, improwizacji i niekontrolowanego strumienia życia na ekranie.

Dzisiaj można zaobserwować renesans scenorysów. Wim Wenders, Patrice Chéreau, Jean-Pierre Jeunet, Mathieu Kassovitz, Roman Polański, a nawet Lars von Trier często wykorzystują scenorysy w swojej pracy reżyserskiej. Widocznie pamiętają słynne zdanie Orsona Wellesa: „Gdy wchodzicie na plan musicie wiedzieć, gdzie postawić kamerę. Inaczej z całą pewnością zaatakują was małe, wewnętrzne złe duchy i te wątpliwości będą widoczne na ekranie”.

Analiza powyższych przykładów wyraźnie pokazała, że scenorys jest podstawowym sposobem, narzędziem i materiałem do pracy nad wizualną strony filmu. Jest więc podstawowym elementem w notatniku reżysera.

Wiemy, jak scenorys powstaje. Zreasumujmy więc elementy, z których się rodzi, które wyraźne wpływają na jego treść i formę. Po pierwsze kształt scenorysu jest pochodną treści scenariusza, wynika z jego analizy.

Po drugie wynika z prób z aktorami, którzy są najważniejszym elementem sceny filmowej. Wnoszą do niej prawdę, ruch, dynamikę, jednym słowem - życie.

Przede wszystkim jednak scenorys jest rezultatem myślenia reżysera, a czasem także i operatora, o filmie, o jego stronie wizualnej, 
emocjonalnej i artystycznej. Jest zapisem ujęć, które należy wykonać w okresie zdjęciowym.

Dlatego bezwzględnie należy pamiętać, że każdy scenorys jest inny, bo każdy film jest inny. Sposób pracy nad scenorysem i co za tym idzie jego finalny kształt zależy od filmu, jaki chcemy zrobić. Nie ma scenorysu idealnego wzorca.

Spróbujmy teraz szczegółowo określić funkcje, które może scenorys spełniać w warsztacie reżysera:

a. artystyczno-koncepcyjna - wyprowadza myśl za pomocą obrazu. Pomaga znaleźć metodę kręcenia. Jest zapisem koncepcji artystycznej kadru, ujęcia, sceny i sekwencji, obrazuje strukturę opowiadania. Pozwala znaleźć nie tylko miejsce ustawienia kamery, ale także odpowiedzieć na pytanie: po co tam stawiać kamerę!

b. montażowa - przewiduje sposób montażu, a także warianty montażowe w scenie. Przewiduje styki scen, na których można zbudować upływy czasu, skoki lub płynność narracyjną, rytm opowiadania, a nawet dodatkowe znaczenia.

c. twórcza - jest brulionem reżysera, podstawą pracy na planie zdjęciowym, bazą do dalszych poszukiwań, punktem odbicia do zmian. To swoisty dziennik filmu, ale dotyczący wydarzeń w przyszłości.

d. komunikacyjna - pomaga w kontakcie ze współpracownikami, z ekipą, która wie, co będzie kręcić i JAK!

e. techniczna - określa, jakie będą używane obiektywy, czy potrzebna jest jazda, ramię, efekty specjalne, dymy, deszczownica itp.

f. produkcyjna - przez pokazanie miejsc ustawień kamery oraz określenie ilości ujęć, można zaplanować kolejność kręcenia, ułożyć plan zdjęć, określić ich koszty itp.

Ktoś powiedział, że scenorys ogranicza wyobraźnię... Moim zdaniem jest wprost przeciwnie - praca nad scenorysem uruchamia wyobraźnię. Scenorys pozwala reżyserowi zobaczyć fragmenty przyszłego filmu. W żadnym wypadku nie należy go traktować jako formy zamkniętej, scenorys nie jest „biblią”! Jest punktem wyjścia do dalszej pracy, niczego nie ogranicza!

Reżyser rysuje kolejne wersje scenorysu przez cały okres pracy nad filmem, tak jak wcześniej scenarzysta robił kolejne wersje zapisu literackiego, czyli drafty scenariusza.

Zanim zacznę kręcenie zdjęć muszę wiedzieć, JAK je nakręcić. Nie mogę tego „jak" szukać rozpaczliwie na planie. Bo wtedy nigdy nie narodzi mi się „coś” więcej, nie powstanie coś tajemniczego, niezaplanowanego. Takie „coś” rodzi się rzadko, ale zdarza się, że nagle z kadru, ze sceny, z aktora wycieka jakaś tajemnica, jakaś dziwna energia, coś niezwykłego. Muszę być przygotowany, by ją złapać. Muszę być gotowy, by zanotować ją w kamerze. Jeśli będę się zastanawiał na planie, JAK to zrobić, ta energia pryśnie mi w kosmos.

I zostaną demony, o których mówił Orson Welles „małe, wewnętrzne złe duchy” niepewności, załamań, chaosu, które będą widoczne na ekranie. 